\title{
The Impact of Accounting Standards on Pension Investment Decisions
}

\author{
Christian Barthelme \\ Siemens Group, Munich, Germany \\ Paraskevi Vicky Kiosse \\ Department of Accounting \\ Streatham Court, Rennes Drive \\ University of Exeter Business School \\ EX4 4PU, Exeter \\ U.K. \\ Thorsten Sellhorn* \\ Institute for Accounting, Auditing and Analysis \\ LMU Munich School of Management \\ Ludwigstraße $28 \mathrm{RG} / 4$. OG. \\ 80539 Munich \\ Germany
}

(Received: May 2017; accepted: March 2018)

Key words: defined benefit plans, pension accounting, pension investment, IAS 19R JEL classification: G11, G30, G32, G38, M48

* Corresponding author: sellhorn@bw.lmu.de

Paper accepted by Hervé Stolowy. Paper presented at the International Accounting Standards Board Research Forum, Brussels, Belgium, November 28, 2017.

Additional materials are available in an Online Supplement at the journal's Taylor and Francis website.

Acknowledgements: We sincerely thank the Editor, two anonymous reviewers, Nick Anderson (discussant), Saverio Bozzolan, Stefano Cascino (discussant), David Oesch, Katharina Hombach, Anne McGeachin, Eddie Riedl, Katherine Schipper, Harm H. Schütt, Tom Scott, workshop and conference participants at Boston University, Georg-August-Universität Göttingen, LMU Munich School of Management, LUISS Guido Carli, Hochschule St. Gallen, University of Parma, University of Zurich, Siemens AG, the 2016 Annual Congress of the European Accounting Association in Maastricht, the XII. Workshop on Empirical Research in Financial Accounting at the University of Exeter, and the IASB Research Forum 2017 for helpful comments and suggestions. All remaining errors are ours. 


\title{
The impact of accounting standards on pension investment decisions
}

\begin{abstract}
This study analyzes the 'real' effects of accounting standards in the context of defined benefit pension plans. Specifically, we examine the impact of IAS 19R, which increases expected pension-induced equity volatility by eliminating the so-called 'corridor method', a smoothing device for actuarial gains and losses. Supported by interview evidence, we show that IAS 19R leads firms to reconsider their pension investment decisions. Using matched samples of treatment and control firms, results from multivariate difference-in-differences tests indicate that firms affected by the adoption of IAS 19R significantly shift their pension assets from equities into bonds, relative to control firms. This effect is attenuated for firms with larger and better funded pension plans. Supplementary analyses suggest that this shift in pension investment is mainly due to IAS 19R's changes in the accounting for actuarial gains and losses (the 'OCI method'). These results are robust to several sensitivity tests, although endogeneity concerns cannot be fully ruled out. Our study informs accounting standard setters and other stakeholders of potential shifts in firms' real economic activities due to concerns about pension-induced equity volatility.
\end{abstract}

Key words: defined benefit plans, pension accounting, pension asset allocation, IAS 19R JEL classification: G11, G30, G32, G38, M48 


\section{Introduction}

This study examines whether accounting standards influence firms' 'real' investment decisions regarding the allocation of pension plan assets to asset classes of different risk. Specifically, we analyze the effect of IAS 19R, which eliminated the corridor method, a smoothing device for recognizing actuarial gains and losses under IFRS, on the allocation of plan assets to equities and bonds.

Risk from pension plans is partly driven by the allocation of plan assets. Empirical research on the determinants of the pension asset allocation identifies the funding status of the pension plan (e.g., Bader, Leibowitz, \& Brothers, 1991), taxes (e.g., Tepper \& Affleck, 1974), regulation (e.g., Harrison \& Sharpe, 1983), and the demography of pension plan participants (e.g., Cocco, Gomes, \& Maenhout, 2005), as factors influencing pension investment decisions. However, much of the cross-sectional and time-series variation in pension asset allocations remains unexplained (Rauh, 2009). In particular, evidence on the impact of accounting standards on pension asset allocations is limited (e.g., Kiosse \& Peasnell, 2009).

We investigate whether accounting standards influence the pension asset allocation in a German IFRS setting. Specifically, we use the transition from IAS 19 to IAS 19R in 2013, which alters the recognition of actuarial gains and losses. Under IAS 19, firms were able to smooth pension-induced equity volatility by deferring recognition of actuarial gains and losses under the so-called 'corridor method'. IAS 19R eliminates this smoothing device - instead mandating immediate recognition of actuarial gains and losses in other comprehensive income (the so-called 'OCI method'). Consequently, firms that used to apply the corridor method under IAS 19 are required to adopt the OCI method under IAS 19R. This switch increases expected volatility of pension liabilities, equity book values, and OCI amounts.

The German IAS 19R adoption setting has several distinct advantages that facilitate a difference-in-differences research design to identify whether eliminating the corridor method affects pension asset allocations, and how that effect varies with cross-sectional differences in pension plan characteristics. First, in contrast to many other IFRS jurisdictions, the German setting offers a sufficiently large treatment sample, as well as a group of control firms unaffected by the accounting change of interest (i.e., firms that already applied the OCI method before IAS 19R mandated it). Second, sample firms exhibit sufficient variation in their exposure to defined benefit pension plans that allows us to examine whether such exposure moderates the effect of the accounting change on the pension asset allocation. Third, this single- 
country setting allows us to effectively limit potential alternative explanations for observed changes in pension asset allocations between treatment and control firms.

Drawing on theory as well as interview-based evidence and firms' public statements, we derive and test two empirical predictions. First, we reason that treatment firms, ceteris paribus, expect their adoption of IAS 19R to increase pension-induced volatility in comprehensive income amounts, equity book values, and pension liabilities. Higher levels of volatility could increase credit spreads (Stracke, 2013) and the likelihood of debt covenant violations. Pension-induced volatility can be mitigated by shifting pension assets out of asset classes that are volatile, and that are positively correlated with fluctuations in net pension liabilities. Accordingly, to mitigate this expected increase in volatility, we predict that, on average, treatment firms reduce the portion of pension plan assets allocated to equities relative to control firms that already apply the OCI method. Second, we expect this effect to vary according to treatment firms' exposure to pension plans and treatment firms' pension plan funding levels.

Univariate comparisons and multivariate regression tests support these predictions. We find that treatment firms significantly reduce (increase) their portion of equity (bond) investments relative to control firms after IAS 19R adoption. This finding is consistent with firms using the allocation of pension assets to mitigate expected volatility arising from exposure to pension plans. In line with the second hypothesis, we show that these effects are attenuated for treatment firms with exposure to larger and better-funded pension plans.

In supplemental analyses, we further explore the source of this 'IAS 19R effect'. Specifically, in addition to changing the accounting for actuarial gains and losses ('OCI effect'), IAS 19R simultaneously alters the calculation of net periodic pension expense by replacing the expected rate of return assumption by the discount rate assumption. Employing a difference-in-differences test that effectively isolates this 'expected rate of return effect' (hereinafter: ERR effect), we find evidence inconsistent with the ERR effect driving our main findings. These results differ from those reported in a concurrent study of Canadian firms (Anantharaman \& Chuk, 2017), highlighting the need for careful jurisdiction-level studies, as the effect of (changes in) accounting standards will likely differ across countries.

Several sensitivity analyses support the robustness of our main results. Specifically, we repeat the main tests using an alternative propensity-score matching approach, several alternative treatment dates and measurement windows, additional and alternatively specified control variables, as well as subsamples. Overall, these sensitivity analyses are consistent with the main findings, although some are weaker, presumably due to lower test power. 
The contribution of this study is threefold. First, we add to the literature on accounting standards as a determinant of pension asset allocations (e.g., Amir \& Benartzi, 1999; Amir, Guan, \& Oswald, 2010; Anantharaman \& Chuk, 2017). Our identification strategy and interview evidence allow us to document a plausibly causal effect of a change in accounting standards on firms' pension asset allocations. Second, we extend prior literature on the economic consequences of accounting standards. Specifically, findings are consistent with the notion that firms adjust their 'real' activities, including their investment behavior, to mitigate the undesired impact of recognition rules on the volatility of equity book values and other key financial statement items (e.g., Zhang, 2009; Choudhary, Rajgopal, \& Venkatachalam, 2009). Third, this study also informs the ongoing deliberations on accounting standards for definedbenefit pension plans, as it suggests that managers' concerns about equity volatility complement widely documented concerns about earnings volatility in influencing manager behavior. These results also inform standard setters' considerations regarding the future role of OCI. Finally, taken together with concurrent work in this field, our study highlights that the effects of accounting standards can vary across countries, reinforcing the need for jurisdiction-level analyses to understand and possibly predict these effects and their drivers.

Section 2 provides background and develops our predictions. Section 3 explains the research design and identification strategy and describes the sample and data. Section 4 presents the main findings, alternative analyses, and robustness tests. Section 5 concludes. Supplemental material is included in a comprehensive Online Appendix.

\section{$2 \quad$ Background and Hypotheses}

\subsection{Accounting Change of Interest: IAS 19R}

\subsubsection{Accounting for Defined Benefit Pension Plans under IFRS}

Firms account for their defined benefit pension plans under IAS 19 Employee Benefits (originally adopted in 1998). IAS 19R, an amendment issued in June 2011 (IFRS Foundation 2011), alters the expected equity volatility of affected firms (i.e., the treatment group). We expect IAS 19R to change how treatment firms allocate their pension assets, relative to an unaffected control group. IAS 19R introduces two noteworthy changes: The first relates to the 
balance sheet depiction of defined benefit plans (herein referred to as the "OCI effect"), and the second affects their income statement presentation (the "ERR effect"). ${ }^{1}$

Describing these effects requires some background. The pension liability (or asset) is the net amount of the defined benefit obligation (DBO) and any externally funded plan assets. This net funded status is either a funding deficit (plan assets < DBO) or surplus (plan assets > DBO). IAS 19 allowed firms to recognize a net pension liability on the balance sheet that adjusts this net amount for any actuarial gains and losses. ${ }^{2}$ Specifically, IAS 19 provides a choice between three different methods of accounting for actuarial gains and losses: (1) deferred recognition in profit or loss (corridor method); (2) immediate recognition in other comprehensive income (OCI method); and (3) immediate recognition in profit or loss. ${ }^{3}$

\subsubsection{The "OCI Effect"}

The corridor method and the OCI method differ dramatically in their effects on firms' balance sheets. Under the corridor method, firms recognize actuarial gains and losses only in part, and only if the cumulative amount exceeds a certain threshold, commonly referred to as the "corridor'. Consequently, corridor method balance sheets fail to fully display pension plans' funded status, which allows firms to largely avoid undesirable pension-induced equity volatility and leverage. In contrast, the OCI method requires all actuarial gains and losses to be recognized when incurred, bringing the pension plan's full funded status onto the balance sheet. Of note, earnings under the OCI method still do not reflect the volatility of net pension liabilities, as actuarial gains and losses are recognized in OCI rather than profit or loss.

IAS 19R eliminates the corridor method (method 1 above) and immediate P\&L recognition (method 3 above), making the OCI method mandatory. Therefore, the treatment group (control group) consists of firms using the corridor method (OCI method) before IAS 19R took effect. When adopting IAS 19R, treatment firms recognize their unrecognized actuarial

1 We thank an anonymous reviewer for stressing that IAS 19R requires additional pension-related disclosures that could also influence affected firms' de-risking behavior through a 'real effect' (e.g., Kanodia, 2007; Leuz \& Wysocki, 2016). However, since these new disclosure requirements affect both treatment and control firms, our difference-in-differences research design should eliminate their effects. Hence, although we consider the derisking effects of pension disclosures to be an important research question, the present setting is not particularly conducive to studying them.

2 Actuarial gains and losses arise for DBOs and plan assets if firms experience adjustments to actuarial assumptions, or change these assumptions for future periods. Actuarial assumptions relating to the DBO include the discount rate, mortality rates, and salary trends. For example, actuarial losses (gains) result when the pension discount rate decreases (increases), which increases (decreases) the DBO.

3 Method (3) was virtually nonexistent in the initial sample (see Table 1 and Glaum, Keller, \& Street, 2018). 
gains or losses on the balance sheet. ${ }^{4}$ In subsequent periods, net pension liabilities reflect any actuarial gains and losses when incurred, making equity amounts and leverage ratios more volatile. We refer to this aspect of IAS 19R - the full recognition of actuarial gains or losses on the balance sheet and within OCI - as the "OCI effect" of IAS 19R. Online Appendix 1 presents a comprehensive numerical example illustrating IAS 19R's OCI effect.

\subsubsection{The "ERR Effect"}

The second noteworthy change in IAS 19R relates to the income statement depiction of defined benefit pension plans. Income statements display a net periodic pension cost that captures service cost, interest cost, and the expected yield on plan assets. Under the original IAS 19 , interest cost was calculated by applying the pension discount rate to the DBO, whereas the expected asset yield reflected the expected rate of return on plan assets (ERR), given the current asset allocation. Under IAS 19R, interest cost and the expected return on plan assets are combined into a net interest cost, calculated as the funded status times the discount rate. Where the expected rate of return on plan assets (say, 6\%) exceeds the discount rate (say, $2 \%$ ), net interest cost under IAS $19 \mathrm{R}$ (DBO x 2\% less plan assets $\times 2 \%$ ) is larger than net interest cost under the original IAS 19 (DBO $\times 2 \%$ less plan assets $\times 6 \%$ ). We label this aspect of IAS $19 \mathrm{R}$ - the elimination of the expected rate of return assumption - the "ERR effect". Evidence in Bergstresser, Desai, and Rauh (2006) and Chuk (2013) is consistent with managers increasing risk in pension asset allocations to justify inflated ERRs, which - before IAS 19R - directly increased reported earnings. Based on these findings, Anantharaman and Chuk (2017) expect and find evidence consistent with IAS 19R's ERR causing reduced risk-taking in pension asset allocations for a sample of Canadian firms.

\subsubsection{Relevance of IAS 19R for the Allocation of Pension Assets}

Any ERR effect notwithstanding, we expect IAS 19R to affect firms' pension asset allocation decisions through the OCI effect, which increases expected pension-induced equity volatility, i.e., volatility in accounting amounts and related ratios caused by the recognition of actuarial gains and losses in OCI and the net pension liability. Recall that the ERR effect operates through managers losing their incentive to invest in risky pension assets as a justification for inflated ERRs and higher earnings. In contrast, the OCI effect does not assume previously biased asset allocations. Rather, it is based on managers expecting increased equity volatility

4 In 2012, treatment firms' mean unrecognized actuarial losses were $€ 981$ million, or $10 \%$ of equity book value. 
under IAS 19R. Whereas firms were able to avoid this volatility under the corridor method, IAS 19R eliminates this possibility. Furthermore, we argue that the OCI effect is of high potential magnitude. For example, Volkswagen AG, the German automaker, recognized a $€ 7,929$ b pre-tax actuarial loss in OCI in 2013 , which amounts to $8.8 \%$ of book equity. The ERR effect, in comparison, would have amounted to roughly $0.04 \%$ of book equity. ${ }^{5}$ As further developed in section 2.3, firms could mitigate expected pension-induced equity volatility by shifting investments into (1) less volatile asset classes, and/or (2) asset classes that provide a natural hedge against expected volatility in the defined benefit obligation. ${ }^{6}$

\subsection{Prior Literature}

By analyzing firms' pension asset allocation decisions in response to a change in pension accounting standards, this paper relates to two streams of literature: First, the 'real effects' literature is interested in the impact of accounting standards on firms' 'real' operating, investing, and financing decisions (e.g., Kanodia, 2007). For example, extant findings suggest that managers alter business decisions to influence accounting outcomes (e.g., Graham, Harvey, \& Rajgopal, 2005; Chuk, 2013), and to mitigate the impact of mandated accounting changes (e.g., Choudhary et al., 2009; Zhang, 2009). As defined benefit pensions are economically large, changes in pension accounting are likely to trigger such 'real' effects. For example, Beaudoin, Chandar, and Werner (2010) show that the adoption of SFAS 158 (which also introduced the OCI method) in the U.S. is associated with firms' decisions to freeze defined benefit pension plans.

Second, a series of papers in finance explain variation in pension asset allocations by the demographics of employees, regulation, taxation, and corporate financial policy; however, unexplained variation remains (e.g., Rauh, 2009). At the same time, practitioners and academics have long held that accounting standards also influence the pension asset investment strategy through their effects on financial statement volatility (Kiosse \& Peasnell, 2009).

5 The ERR effect is difficult to calculate precisely from public disclosures. For example, Volkswagen reports separate discount rates and expected rates of return on plan assets for Germany versus all other countries, but does not provide the same disaggregation for the DBO and the fair value of plan assets. However, assuming that Volkswagen replaced the 2012 expected rate of return on plan assets for Germany (4.12\%) with the 2013 discount rate for Germany $(3.70 \%)$, and applied the difference $(0.42$ percentage points) to the fair value of plan assets at the end of 2012 ( $€ 7.288 \mathrm{~b}$ ), this would have led to a pension expense that would have been higher by $€ 31 \mathrm{~m}$, or 0.04 of book equity. Clearly, however, the magnitude of the ERR effect is driven by (1) a firm's fair value of plan assets, and (2) its spread between the discount rate and the expected rate of return on plan assets.

6 In section 4.3, we consider whether IAS 19R's ERR effect is associated with shifts in firms' pension asset allocations. This test amounts to a replication of Anantharaman and Chuk (2017) for the German setting. 
Several prior studies straddle these two lines of research, seeking to assess firms' use of pension asset allocations to mitigate the undesired impact of changes in accounting standards. ${ }^{7}$ Amir and Benartzi (1999) suggest that firms avoid the recognition of an additional pension liability under SFAS 87 by reducing the volatility of pension assets. These inferences are based on cross-sectional tests that control for other known and observable determinants of the pension asset allocation. Amir et al. (2010) provide evidence consistent with firms changing their pension asset allocations to mitigate expected equity volatility from pension accounting changes in the U.K. and U.S. Inferences rely on pre-post comparisons of pension asset allocations around the relevant changes in accounting standards, again using control variables. ${ }^{8}$

We complement these papers in several important ways: First, our single-country difference-in-differences research design mitigates potential concerns that omitted crosssectional (i.e., across-firm) or time-series (i.e., within-firm) factors could explain the observed effects. Second, this study is the first to provide IFRS-based insights from a ContinentalEuropean perspective, and thus speaks to the external validity of prior work. Third, in addition to relying on archival data, we provide insights into key assumptions and mechanisms based on interviews with sample firms' Chief Accounting Officers. Fourth, analyzing the percentage of bonds in addition to equities allows us to assess the extent to which firms not only shift out of risky assets, but also whether this is accompanied by a shift into another asset class consistent with the theoretical predictions of this literature.

In a concurrent study, Anantharaman and Chuk (2017) investigate the ERR effect of IAS 19R in Canada, using U.S. firms as a control group. The authors document a reduced percentage of equity investments after mandatory IAS 19R adoption, in absolute terms as well as relative to the control group. Our study complements Anantharaman and Chuk (2017) in three important ways: First, whereas Anantharaman and Chuk (2017) are interested in IAS 19R's ERR effect, we focus on IAS 19R's OCI effect. ${ }^{9}$ Doing so matters, as eliminating the corridor method, a highly salient and effective smoothing device, had an economically significant impact. Second, the German single-country setting arguably provides a cleaner control group relative to a cross-country design. Third, our findings suggest that German firms' in-

7 These papers are complemented by several studies that document accrual earnings management in the pension context, typically using actuarial assumptions (e.g., Glaum, 2009 for a review).

8 Mashruwala (2008) reports similar findings in the U.K. setting by documenting that U.K. firms reduce equity allocations by approximately 8 percentage points following the introduction of FRS 17 .

9 As discussed in section 4.3, we cannot cleanly separate the OCI and ERR effects in our main setting. However, we complement the main tests with alternative analyses that allow isolation of the ERR effect. (We discuss an empirical approach to isolating the OCI effect, but data availability constraints prevent us from implementing it.) 
centives related to the ERR effect differ from those of Canadian firms, and that these differences seem to matter. Overall, we complement Anantharaman and Chuk (2017) and prior work in investigating the effect of accounting standards on firms' pension asset allocations.

\subsection{Hypothesis Development}

\subsubsection{Key Assumptions and Supporting Evidence}

We predict that treatment firms rebalance their pension asset allocations due to concerns about expected equity volatility caused by IAS 19R. This prediction, developed in section 2.3.2 below, follows from three conditions: Treatment firms (1) expect IAS 19R to increase equity volatility; (2) have incentives to avoid such volatility; and (3) view plan asset reallocation as an effective, efficient (i.e., relatively low-cost), and de-facto feasible countermeasure. In this section, we discuss theory and evidence suggesting that these conditions hold. Our evidence stems from two sources: (a) seven semi-structured interviews with Chief Accounting Officers (CAO) of sample firms ${ }^{10}$, and (b) stakeholders' public statements and comment letters to the IASB.

Regarding condition (1), the discussion in section 2.1 and Online Appendix 1 illustrates the volatility-increasing effect of IAS 19R on treatment firms' book value of equity. But were firms sufficiently aware of this OCI effect to be concerned? Interviewed CAOs uniformly indicate their clear expectation that IAS 19R would increase the volatility of equity (and, in the case of accumulated unrecognized actuarial losses, decrease its magnitude) for treatment firms. Consistent with this view, Deutsche Lufthansa AG states that "changes in the discount rate ... and ... fluctuations in the market value of plan assets, can in particular result in considerable, unpredictable fluctuations in the balance sheet and shifts between equity and liabilities." Lufthansa comments as follows on the elimination of the corridor method: "the 10-per cent corridor rule previously used ... to avoid annual fluctuations in the balance sheet will then no longer be allowed." (Deutsche Lufthansa AG, 2012, both quotes). Deutsche Post AG also expressed concerns in relation to the immediate recognition of actuarial gains or losses on the balance sheet in their comment letter submitted in response to the 2010 Exposure Draft that led to the introduction of IAS 19R, noting: "From a conceptual viewpoint, we are not convinced that highlighting short-term volatility provides any additional relevant information

10 Refer to Online Appendix 2 for summary information on these interviews. We present this evidence in the spirit of Gow, Larcker, and Reiss (2016, p. 479), which argues "that evidence on the actions and beliefs of individuals and institutions can bolster causal claims based on associations, even absent compelling estimates of the causal effects." 
to the reader of financial statements and may in addition lead to inefficient investment decisions by entities (in order to avoid such volatility)." These expectations are echoed in audit firms' publications. For example, Ernst \& Young (2011, p. 3) states: “These changes will result in increased balance sheet volatility for those entities currently applying the corridor approach."

Condition (2) states that firms also needed to be concerned about this effect to a sufficient extent for them to consider countermeasures. A first indication lies in the fact that treatment firms chose not to voluntarily adopt the OCI method before it became mandatory under IAS 19R. Consistent with this view, an increase in firms' volatility of comprehensive income, equity and liabilities affects the perception of business risk by equity investors (Jin, Merton, \& Bodie, 2006; Chava \& Purnanandam, 2010) and debtholders (Bao, Billett, Smith, \& Unlu, 2018). Another negative potential consequence is the impact on firms' contractual arrangements. For example, volatility in the book value of equity increases the likelihood of violation of accounting-based debt covenants (Watts \& Zimmerman, 1986). Higher volatility of comprehensive income also affects retained earnings, constraining firms that link dividend payouts to retained earnings. ${ }^{11}$

Consistent with these theoretical considerations, interviewed CAOs point out that equity volatility and depletion are severe concerns that are distinct from concerns about earnings volatility. Equity volatility is considered problematic due to debt covenants that vary with the book value of equity (e.g., debt-to-net worth), and because of capital-market perceptions of default risk. These concerns are corroborated by PIMCO's global head of credit research, who notes that "it's not just about the liability - it's about the volatility of the liability" (Stracke, 2013). The immediate recognition of actuarial gains and losses that occurs under IAS 19R increases the volatility of pension liabilities, which "is a critical factor in credit analysis" (Stracke, 2013). Moreover, Stracke (2013) claims that information previously provided in the notes does not sufficiently enable credit analysts to properly assess pension liabilities and their volatilities, suggesting that IAS 19R will render pension-induced volatility more salient by elevating it from pre-IAS 19R notes disclosures to recognition in the financial statements.

Related to condition (3), there is a widespread perception among practitioners and academics that the pension asset investment strategy can affect financial statement volatility

11 Whereas German corporate law restricts dividend payments to the amount of retained earnings calculated under German GAAP, shareholders may form expectations about dividends on the basis of published IFRS financial statements. Also, as indicated by one interviewee, corporate bylaws and charters occasionally make dividend distribution conditional on maintained minimum ratios of book value of equity to total assets. 
(Kiosse \& Peasnell, 2009). ${ }^{12}$ For example Rauh (2009) shows that incentives to limit costly financial distress explain some of the variation in pension asset allocations. He finds firms decreasing the allocation to equities when they are close to financial distress. Amir and Benartzi (1999) find that firms shift pension assets from equity to fixed-income securities to reduce the risk of recognizing an additional pension liability. Interviewed CAOs also view "liability-driven investment" strategies for plan assets as a proper approach to mitigating the equity volatility concerns raised by IAS 19R. Specifically, they consider it favorable among other measures of "de-risking" pension plans, such as curtailments, settlements and shifts into cash-balance plans, which they deem more costly and feasible only in the long-term.

However, it is not obvious that firms can de facto influence asset allocations where pension plans are administered outside of the reporting entity. Asked directly, several CAOs report that asset management committees consisting of firm managers and independent pension plan trustees/directors decide on asset allocation strategies. This supports the notion that firms have de-facto opportunities to influence pension asset allocations in the expected way.

\subsubsection{Empirical Predictions}

Against this background, the first hypothesis predicts that IAS 19R affects pension asset allocations for firms applying the corridor method in the pre-IAS $19 \mathrm{R}$ period. ${ }^{13}$ These firms now adopt the OCI method, which requires immediate recognition of actuarial gains and losses in other comprehensive income. For these firms, actuarial gains and losses now fully affect balance sheet amounts (i.e., the net pension liability and - through OCI - shareholders' equity), with ripple effects on financial ratios containing either amount, in the period in which they occur. We refer to this effect as the 'OCI effect'. Accordingly, we expect IAS 19R's elimination of the corridor method to increase firms' pension-induced equity volatility.

How would firms reallocate their pension assets to counteract this expected OCI effect? The pension-induced equity volatility caused by actuarial gains and losses flowing through OCI potentially stems from two sources: (1) fluctuations in the DBO (which are predominantly due to discount rate changes), and (2) fluctuations in plans assets. Therefore, firms have an incentive, first, to increase their investments in bonds, which are negatively correlated with

12 Alternative (and potentially costlier, and longer-term) ways of reducing the financial statement risks of pension plans include settlement payments, termination/freezing of existing pension plans, and risk transfers to insurance companies.

13 Again, refer to section 2.1 for a detailed comparison of the two methods of recognizing actuarial gains and losses, and Online Appendix 1 for a numerical example. 
interest rates (e.g., Amir \& Benartzi 1999, Amir et al., 2010), and, second, to the extent that equities are more volatile than other asset classes held within plan assets (and ignoring diversification effects), reduce the percentage of equities. Taken together, we hypothesize that treatment firms mitigate the imminent increase in pension-induced equity volatility by decreasing (increasing) the percentage of equities (bonds) in their pension assets:

H1: When adopting the OCI method under IAS 19R, treatment firms (which previously applied the corridor method) will, on average, reduce (increase) the portion of equities (bonds) in their pension assets, relative to control firms (which already apply the OCI method).

We further expect that this 'OCI effect' predicted under $\mathrm{H}_{1}$ varies in the cross-section with firms' defined benefit pension plan characteristics. Specifically, the volatility effect of IAS $19 \mathrm{R}$ is potentially more severe for firms with relatively large pension plans, as these firms are likely to have larger actuarial gains and losses, leading to higher pension-induced equity volatility. Furthermore, relatively larger plan assets provide larger scope for firms to counteract expected pension-induced equity volatility by decreasing the percentage of equities in their pension assets. For most firms, the magnitude of pension assets and pension obligations relative to book value of equity is considerable. Therefore, these firms could have stronger incentives to rebalance their pension assets as predicted under $\mathrm{H}_{1}$.

However, shifting the relative weights of equities and bonds may be a blunt and weak instrument for managing expected equity volatility - especially where pension plans are large and funding levels are relatively low. In these cases, interviewees note that firms are likely to supplement other measures to counteract IAS 19R-induced equity volatility. These include derivatives-based hedging (which the low granularity of pension asset disclosures prohibits us from observing), defined benefit plan curtailments, settlements, freezes, or closures (which are relatively costly and therefore less likely to occur within a relatively short window around the mandatory adoption of IAS 19R), and cash injections into plan assets. Therefore, we make the following unsigned prediction:

H2: When adopting the OCI method under IAS 19R, treatment firms' relative reduction (increase) in the portion of equities (bonds) in pension assets will, on average, vary with firms' (a) exposure to pension plans and (b) level of funding deficits. 


\subsection{Institutional Setting}

The within-Germany setting provides a sufficiently large number of public firms with substantial, but varying, exposure to defined-benefit pension plans. These firms' IFRS reporting is subject to a rigid enforcement mechanism (e.g., Hitz, Ernstberger, \& Stich, 2012) and exhibits high data quality. As only a subset of firms are affected by IAS 19R's elimination of the corridor method, this setting facilitates a single-country difference-in-differences design.

In Germany, defined benefit pension plans are funded either internally (i.e., through the sponsoring firm's operating or financial assets), externally (i.e., through a separate funding agency that manages plan assets on the firm's behalf), or through a combination of both. In the case of external funding, funding agencies invest firms' contributions into various asset classes (e.g., equity instruments, bonds, real estate, or cash). Funding agencies include pension funds, contractual trust arrangements (CTAs), support funds, and insurance-like vehicles. Pension plan sponsors and funding agencies face numerous regulatory requirements, and the German setting is no exception. However, and importantly for this study, none of these requirements provide plausible explanations for mean shifts in the pension asset allocations of treatment firms relative to control firms in the context of IAS 19R adoption. ${ }^{14}$

\section{$3 \quad$ Research Design and Data}

\subsection{Identification Strategy and Regression Models}

This section explains our approach to identifying the causal effect of IAS 19R on firms' pension plan asset allocations.

\subsubsection{Modeling the Pension Asset Allocation}

Following Amir et al. (2010), hypothesis tests rely on the following baseline regression to explain cross-sectional variation in the pension asset allocation:

$$
\begin{aligned}
\text { ASSET_ALLOC } C_{\mathrm{it}}=\alpha_{0} \quad & +\alpha_{1} \text { Lev }_{\mathrm{it}}+\alpha_{2} F F_{\mathrm{it}}+\alpha_{3} \text { Size }_{\mathrm{it}}+\alpha_{4} S D C F_{\mathrm{it}}+\alpha_{5} F_{u n d} \mathrm{it}_{\mathrm{it}} \\
& +\alpha_{6} \text { Horizon }_{\mathrm{it}}+\alpha_{7} \operatorname{Exp}_{\mathrm{it}}+\sum_{k=8}^{18} \alpha_{k} I_{\mathrm{it}}+\varepsilon_{\mathrm{it}}
\end{aligned}
$$

14 In Online Appendix 3, we further discuss the German regulatory environment in terms of three distinct institutional factors that prior studies have linked to variation in pension sponsors' plan asset allocations: (1) restrictions on funding agencies' investment strategies; (2) funding requirements and insurance; and (3) taxation. The purpose of that discussion is to show that these institutional factors are unlikely to explain the empirical patterns we observe in the context of IAS 19R adoption. 
The dependent construct, $A S S E T \_A L L O C_{i t}$, reflects two alternative measures that characterize firms' pension asset allocations: $\% E Q_{i t}\left(\% B O N D S_{i t}\right)$ is the percentage of pension assets invested in equity securities (bonds) of firm $i$ at the end of fiscal year $t .{ }^{15}$ Prior literature identifies several determinants of firms' pension asset allocations, which are included in equation (1). First, firms with higher leverage ratios (Lev) are expected to be (on average) closer to violating their debt covenants, which creates incentives to decrease pension-induced equity volatility by investing more (less) pension assets in bonds (equities) (e.g., Mitra \& Medova, 2010).

Second, the percentage of free float $(F F)$ captures the presence of large blockholders. Findings in Faßhauer, Glaum, Keller, and Street (2011) suggest that firms with large shareholders are more effectively monitored, which could mitigate managers' compensationrelated incentives to promote risk taking that manifests in the pension asset investment strategy (Anantharaman \& Lee, 2014). We therefore expect a positive (negative) relation between $F F$ and $\% E Q(\% B O N D S)$.

Third, we control for firms' business risk by introducing firm size (Size) and the variability of operating cash flows $(S D C F)$. To the extent firms' cash flows are positively correlated with stock returns (e.g., due to decreasing plan assets triggering cash funding requirements; Amir \& Benartzi, 1999), firm risk increases in \%EQ. Hence, we predict a negative (positive) relation between $S D C F$ and $\% E Q(\% B O N D S)$. Furthermore, as large firms are associated with lower business risk (e.g., Fama \& French, 1993), we predict a positive (negative) relation between Size and \%EQ (\%BONDS).

Fourth, prior literature also identifies pension plan funding levels as determinants of the pension asset allocation. Analytical research by Harrison and Sharpe (1983) suggests that firms should invest pension assets in equity securities if funding levels are low, increasing the value of the put option provided by a pension guarantee system. However, German legislation requires minimum funding of externally funded pension plans, which reduces the value of the put option. Moreover, in contrast to the theoretical prediction, Rauh (2009) and Anantharaman and Lee (2014) find that firms with higher funding levels allocate more pension assets to equity securities. We include the funding status (Fund; i.e., the fair value of plan assets scaled by the DBO), but due to conflicting findings in prior literature, we refrain from predicting a sign. ${ }^{16}$

15 We suppress subscripts in the subsequent text. See Appendix A for detailed variable definitions.

16 Alternatively, we test for a non-linear relation between $F u n d$ and $\% E Q$ as well $\% B O N D S$ in section 4.4.4. 
Fifth, we include the investment horizon of pension assets (Horizon). DBOs reflect estimated future payments and the discount rate. Whereas estimated future payments depend heavily on expected final salary levels, the discount rate reflects market yields of high-quality corporate bonds. Accordingly, DBOs for retirees are primarily affected by short-term interest rates, whereas DBOs for younger, active workforces are more strongly correlated with value changes in equities. Consistent with firms hedging against increases in DBOs caused by rising salaries (Sundaresan \& Zapatero, 1997; Cocco et al., 2005), Bikker, Broeders, Hollanders, and Ponds (2012) find that older employees are associated with lower equity investments. Therefore, we predict a positive (negative) relation between Horizon and \%EQ (\%BONDS).

Sixth, consistent with our reasoning in section 2.3.2, we control for the exposure of firms' book value of equity to the size of the pension plan (Exp), measured as the ratio of pension assets to book value of equity. ${ }^{17}$ We refrain from predicting a sign for this relation.

Finally, equation (1) is estimated including a set of 11 industry indicator variables (Ind).

\subsubsection{Identifying the IAS 19R Effect}

We adopt the difference-in-differences research design illustrated in Figure 1 to test our predictions. Specifically, we measure the effect of mandatory IAS 19R adoption on the pension asset allocation by comparing differences in pension asset allocations between a treatment group affected by IAS 19R and an unaffected control group across the pre- and post-IAS 19R periods. This design helps us isolate the causal IAS 19R effect by excluding time-invariant factors and time-series mean shifts affecting both groups.

\section{FIGURE 1 ABOUT HERE}

Whereas treatment firms switch from the corridor method to the OCI method under IAS 19R, control firms already used the OCI method and are therefore unaffected. To quantify the effect of mandatory IAS 19R adoption on the pension asset allocation, we first measure the difference in the percentages of equities and bonds, $\% E Q$ and $\% B O N D S$, between the two groups before the transition to IAS 19R (effect 1 in Figure 1). In a second step, we remeasure these differences after IAS 19R adoption (effect 2). To test $\mathrm{H}_{1}$, we calculate the difference between these pre- and post-IAS 19R differences (effect 3). This design controls for trends in pension asset allocations shared by both groups as well as observable and unobservable timeinvariant firm characteristics; it thus mitigates potential selection bias (Lennox, Francis, \&

17 In section 4.2, we discuss results for an alternative measure of pension plan exposure. 
Wang, 2012). In addition, we use control variables to capture the effects of any observable time-variant firm characteristics that differ across the treatment and control groups.

Figure 1 also illustrates the pre- and post-treatment periods around the transition to IAS 19R. IAS 19R was issued by the IASB on June 16, 2011, obtained EU endorsement in June 2012, and became effective for fiscal years beginning on or after January 1, 2013. Importantly, the preceding 2010 exposure draft (IFRS Foundation 2010) was already very much in line with the final IAS 19R, in that it proposed the OCI method as the only permitted approach to accounting for actuarial gains and losses. As affected firms required time to analyze the new requirements and evaluate their consequences, we assume any IAS 19R-induced change in pension asset allocations to start becoming visible in 2012. This assumption is consistent with prior literature using difference-in-differences research designs to examine the effect of changes in regulations and laws (e.g., Agrawal, 2013).

We structure our analysis over a four-year window centered on IAS 19R adoption. Specifically, we treat fiscal years 2010 and 2011 (2012 and 2013) as the pre-treatment (posttreatment) period. This choice of window length in the post-treatment period reflects a tradeoff between allowing sufficient time for firms to adjust their pension asset allocations and the risk of a longer window capturing confounding factors that might explain deviating levels of $\% E Q$ and \%BONDS across the two groups (Roberts \& Whited, 2013). ${ }^{18}$ To apply the difference-in-differences design, we extend equation (1) by the variables TREAT and Post. TREAT is the treatment assignment variable that equals 1 if a firm has applied the corridor method before the treatment, and 0 otherwise. Post is an indicator variable that equals 1 for posttreatment periods, and 0 otherwise. To compare changes in the pension asset allocation across the treatment and control firms before and after the treatment, we introduce the interaction term Post $\times$ TREAT. We test $\mathrm{H}_{1}$ using the following regression:

$$
\begin{aligned}
A S S E T \_A L L O C_{\mathrm{it}}=\beta_{0} \quad & +\beta_{1} \text { TREAT }_{\mathrm{it}}+\beta_{2} \text { Post }_{\mathrm{it}}+\beta_{3} \text { Post } \times \text { TREAT }_{\mathrm{it}} \\
& +\sum_{k=4}^{21} \beta_{k} \text { Controls }_{\mathrm{it}}+\varepsilon_{\mathrm{it}}
\end{aligned}
$$

In equation (2), Controls captures the control variables included in equation (1), TREAT captures pre-treatment differences across the treatment and control groups, and Post captures the treatment effect on the control group. The main coefficient of interest, $\beta_{3}$ on Post $\times$ TREAT, captures the incremental treatment effect on ASSET_ALLOC (i.e., \%EQ and $\% B O N D S$, respectively) in the treatment group relative to the control group (i.e., the differ-

18 In section 4.4.1 we discuss robustness tests using alternative time windows. 
ence-in-differences). If treatment firms reduce (increase) their percentage of equities (bonds) more strongly than control firms $\left(\mathrm{H}_{1}\right)$, we predict $\beta_{3}$ to be negative (positive).

$\mathrm{H}_{2}$ predicts that treatment firms' pension plan characteristics affect the 'IAS 19R effect' on $\% E Q$ and $\% B O N D S$. To empirically test this prediction, we extend equation (2) by adding interactions between two different proxies for pension plan characteristics $\left(P P \_C H A R\right)$ and Post $\times$ TREAT, yielding the following regression:

$$
\begin{aligned}
\text { ASSET_ALLOC } \mathrm{it}_{\mathrm{it}}=\gamma_{0} & +\gamma_{1} \text { TREAT } T_{\mathrm{it}}+\gamma_{2} \text { TREAT } \mathrm{x} P P_{-} C H A R_{\mathrm{it}}+\gamma_{3} \text { Post }_{\mathrm{it}} \\
& +\gamma_{4} \text { Post } \mathrm{x} P P_{-} \text {CHAR } \mathrm{it}_{\mathrm{it}}+\gamma_{5} \text { Post } \mathrm{x} \text { TREAT } T_{\mathrm{it}} \\
& +\gamma_{6} \text { Post } \mathrm{x} \text { TREAT } T_{\mathrm{it}} \times \text { PP_CHAR } \mathrm{R}_{\mathrm{it}} \\
& +\sum_{k=7}^{24} \gamma_{k} \text { Controls }_{\mathrm{it}}+\varepsilon_{\mathrm{it}}
\end{aligned}
$$

PP_CHAR reflects either (1) Exp, the magnitude of the firm's pension plan, measured as the ratio of pension assets to the book value of equity, or (2) Fund, a measure of a firm's pension plan funded status. ${ }^{19}$ We interact PP_CHAR with TREAT, Post and Post $\times$ TREAT, respectively, to test whether the 'IAS 19R effect' (i.e., treatment firms' relatively larger change in the pension asset allocation compared to control firms) is more pronounced for firms with larger or more strongly underfunded pension plans.

In equation (3), Post $\times$ TREAT $\times$ PP_CHAR is the incremental pre- to post-treatment change in ASSET_ALLOC for treatment firms with high values of PP_CHAR, relative to those with low values. In line with the unsigned expression of $\mathrm{H}_{2}$, we predict no direction for the coefficients on these interactions, $\gamma_{6}$. All models are estimated using pooled OLS regressions with standard errors clustered by firm and year.

\subsubsection{Addressing Self-Selection Bias}

Estimating causal effects of accounting standards poses the challenge that control samples often are either unavailable or non-randomly assigned, where the latter circumstance gives rise to the potential presence of correlated omitted variables. The German setting does provide the advantage of a set of control firms. However, these self-select into the control group by voluntarily adopting the OCI method - using an accounting choice offered under the original IAS 19 and eliminated by IAS 19R. In contrast, treatment firms switch to the OCI method only when forced to do so as IAS 19R becomes mandatory. To the degree that factors driving this accounting choice are correlated with firms' pension asset allocations (\%EQ and

19 Both measures capture (i) the sensitivity of firms' equity book values to pension-induced volatility and, simultaneously, (ii) the degree to which firms can mitigate that volatility by adjusting pension asset allocations. 
$\% B O N D S$ ), coefficients on the independent variables could suffer from correlated omitted variable bias (Roberts \& Whited, 2013), distorting inferences from the main test.

As our difference-in-differences design does not fully rule out these concerns, we construct the control sample through propensity-score matching based on firm characteristics that we expect to explain the choice between the corridor and the OCI methods. The matching procedure is intended to strengthen the key assumption of covariate balance across treatment and control firms, which mitigates the potential impact of correlated omitted variables (e.g., Rosenbaum, 2010). Collectively, this matching procedure and the difference-in-difference research design help us mitigate endogenous self-selection concerns, with the sole possible exception of unobserved time-variant firm characteristics that deviate across groups. ${ }^{20}$ While we cannot rule out this possibility, we have no reason to suspect such factors in our setting.

We derive inputs for calculating the propensity scores by considering determinants of the choice of TREAT. Consistent with prior work (e.g., Glaum et al., 2018; Faßhauer et al., 2011; Morais, 2010), we model firms' choice of TREAT as a function of variables broadly capturing (1) the materiality of the pension plan; (2) expected exposure to pension-induced equity volatility; and (3) a firm's commitment to transparency and industry best practice. This leads to the following probit regression, which predicts firms' pre-IAS 19R choice of the corridor versus OCI methods (i.e., TREAT):

$$
\begin{aligned}
& \operatorname{Prob}(\text { TREAT }=1)=\delta_{0} \quad+\delta_{1} \text { Lev }_{\mathrm{it}}+\delta_{2} F F_{\mathrm{it}}+\delta_{3} \text { Size }_{\mathrm{it}}+\delta_{4} S D C F_{\mathrm{it}}+\delta_{5} F u n d_{\mathrm{it}} \\
& +\delta_{6} \text { Horizon }_{\mathrm{it}}+\delta_{7} \operatorname{Exp}_{\mathrm{it}}+\sum_{k=8}^{18} \delta_{k} \text { Ind }_{\mathrm{it}}+\varepsilon_{\mathrm{it}}
\end{aligned}
$$

As above, the indicator variable TREAT captures observations representing treatment firms that choose to apply the corridor method in the pre-IAS 19R adoption period (recall that only these firms are affected by mandatory IAS 19R adoption). Accordingly, TREAT assumes a value of 0 for control firm observations (i.e., representing firms that already applied the OCI method prescribed under IAS 19R before it was mandated).

The corridor method mitigates pension-induced volatility in income statement and balance sheet amounts. Accordingly, equation (4) mainly includes explanatory variables from equation (1). We expect exposure to material pension plans (Exp) to affect the choice, as the corridor method mitigates pension-induced equity volatility, which increases in exposure. Similarly, a firm is more sensitive to pension-induced equity volatility, making the choice of the corridor method more likely, if it has higher leverage (Lev), lower free float $(F F)$, higher

20 Specifically, for results to be explained by an omitted variable, that variable would have to vary contemporaneously with IAS 19R adoption, and affect treatment and control firms differently. 
risk (SDCF and Size), a longer investment horizon (Horizon), and a lower funding ratio (Fund). Finally, we capture a firm's industry best practice by adding industry indicators. ${ }^{21} \mathrm{We}$ estimate equation (4) using data for 2011, i.e., one year before the treatment date, across all firms listed in the Prime Standard as of January 1, 2014, and which have available data according to the sample selection process outlined in section 3.2. This allows us to use pretreatment characteristics when matching treatment and control firms. We use one-to-one (i.e., single nearest neighbor) matching without replacement. ${ }^{22}$

\subsection{Sample and Data}

Table 1 illustrates the sample selection process. Sample firms are listed in Deutsche Börse Group's Prime Standard segment as of December 12, 2014. ${ }^{23}$ We eliminate firms that do not sponsor externally funded defined benefit pension plans. We also drop firms that recognize actuarial gains and losses immediately in profit or loss (i.e., method 3 in section 2.1), as these firms should not expect IAS 19R to increase their equity volatility. Moreover, we exclude firms that invest pension assets solely in insurance contracts, as firm management cannot affect the investment strategy for these assets (violating assumption 3 in section 2.3.1). Finally, we eliminate firms with insufficient information on the pension asset allocation. We are left with 90 unique firms in the main analyses: 41 potential treatment firms using the corridor method, and 49 potential control firms using the OCI method.

\section{TABLE 1 ABOUT HERE}

The sample period spans four fiscal years, 2010 to $2013 .{ }^{24}$ Our research design employs a balanced panel of treatment and control firms to enhance pre- and post-treatment compara-

21 Data constraints preclude us from including cumulative unrecognized actuarial gains and losses, another likely factor of influence. This is due to cumulative actuarial gains and losses not arising under the OCI method. However, our interview suggests that cumulative actuarial gains and losses were an important determinant of the choice of corridor versus OCI method only for early adopters switching to the OCI method in or shortly after 2005. Further, comprehensive evidence in Glaum et al. (2018) documents that cumulative actuarial gains/losses explain firms' OCI adoption decisions in 2005 - but not between 2006 and 2013. We thus believe that omitting cumulative actuarial gains/losses from a selection model estimated in 2011 will not result in severe omitted variables problems.

22 We also carry out robustness tests using caliper matching in section 4.4.3.

23 The Prime Standard segment comprises 340 listings representing 319 unique firms. (Several firms have both common stock and preferred stock outstanding; these count as separate listings.) We select this particular market segment, as it imposes transparency standards that go beyond EU minimum requirements. Besides reporting under IFRS, these firms published quarterly reports in German and English during our analysis period. However, as firms usually do not disclose the pension asset allocation in their interim reports, observations are restricted to one per year. Furthermore, firms listed outside of this segment often lack significant pension plans and typically do not provide sufficient information on pension asset allocations.

24 In robustness tests discussed in section 4.4.1, we vary the event window between 2010-2014 and 2009-2013. 
bility by eliminating effects of time-invariant factors. Therefore, we require firms to have observations and test variables in all of the four analysis periods. This procedure yields 37 treatment firms and 45 control firms. Observing these firms over a four-year period results in 328 firm-year observations. We subsequently match treatment and control firms using the approach discussed in section 3.1.3, yielding a final sample of 216 firm-year observations (108 for treatment firms and 108 for control firms) used in the main analysis.

We obtain financial statement data and pension asset allocation information from Worldscope, ascertaining the quality of the latter by manually verifying Worldscope data with footnote disclosures in firms' annual reports accessed through Perfect Information database. ${ }^{25}$ Finally, to identify treatment and control firms, we also hand-collect the method of recognizing actuarial gains and losses (refer to section 2.1). Finally, we conduct semi-structured interviews with Chief Accounting Officers of several sample firms during the first quarter of 2017; Online Appendix 2 provides related summary information.

\section{$4 \quad$ Empirical Results}

\subsection{Descriptive Statistics}

Panel A of Table 2 provides comparisons for the variables used in the main tests. Regarding the allocation of pension assets, treatment firms on average reduce amounts allocated to equities (\%EQ) from $27.3 \%$ to $23.6 \%$ (a $14 \%$ reduction) between the pre- and post-treatment periods. In contrast, control firms' $\% E Q$ values remain relatively more stable, diminishing from $30.0 \%$ to $27.9 \%$ (a $7 \%$ reduction). Results for $\%$ BONDS are somewhat surprising, showing shrinking proportions allocated to bonds amidst falling interest rates. However, consistent with $\mathrm{H}_{1}$, treatment firms' bond percentage falls by less $(48.3 \%$ down to $46.5 \%$, or $4 \%$ ) than that of control firms ( $47.7 \%$ down to $42.9 \%$, or $10 \%$ ). The significance tests reported in Table 2 suggest that there are no significant differences in the covariates of interest after matching.

\section{TABLE 2 ABOUT HERE}

Figure 2 illustrates these differences-in-differences, indicating that $\% E Q$ and $\% B O N D S$ values for the treatment and control groups exhibit a parallel trend in the pre-treatment period, distinctly drifting apart in the post-treatment period. Difference-in-differences research de-

Note that, during the analysis period, mandated disclosure requirements on the composition of plan assets were limited to a disaggregation of the percentages or amounts of "equity instruments, debt instruments, property, and all other assets" (IAS 19.120A (j)) and "amounts included in the fair value of plan assets for ... the entity's own financial instruments; and ... property occupied by, or other assets used by, the entity" (IAS 19.120A (k)). See Online Appendix 4 for examples of the various degrees of granularity in pension asset disclosures. 
signs assume that the average change in the dependent variable would have been the same for the treatment and control groups absent the treatment (Roberts \& Whited, 2013). This parallel-trends assumption is more plausible if the dependent variable exhibits a similar trend for both groups during the pre-treatment period. Accordingly, we take Figure 2 as initial evidence supporting the parallel-trends assumption. ${ }^{26}$

Two other notable insights emerge from Panel A of Table 2: First, treatment and control firms are relatively comparable in both the pre- and post-treatment periods, across all variables. ${ }^{27}$ Second, whereas most variables do not change significantly across the pre- and posttreatment periods, firms' exposure (Exp) increases by roughly three to five percentage points for the treatment and control group. Clearly, declining discount rates contribute to increased defined benefit obligations and low plan asset yields, increasing firms' exposures. However, constant funding levels indicate that the increasing exposure is caused by relative changes in the book value of equity, which lead to higher exposures for control firms.

Panel B of Table 2 presents correlations for the main variables of interest. Pearson (Spearman) correlations are shown above (below) the diagonal. All Spearman correlations between $\% E Q$ and the control variables (except for $L e v$ ) exhibit the expected signs; they are significant for FF, Fund, and Horizon. All Spearman correlations between \%BONDS and the control variables (except for Size) exhibit the expected signs and are significant for Lev, FF, Size, Fund, Horizon and Exp. As expected, all asset allocation variables (\%EQ, \%BONDS, $\% O T H E R$, and \%PROPERTY) are negatively correlated with each other, as they tend to be substitutes. Correlations among control variables are sufficiently low not to pose multicollinearity concerns, with variance inflation factors below 2.0 in the main tests.

\subsection{Main Results}

Panel A of Table 3 presents univariate tests of differences in $\% E Q$ and $\% B O N D S$ between the treatment and control groups as well as over time. Treatment firms exhibit a decline in $\% E Q$

26 To formally test this assumption, we estimate a model where $\% E Q$ is the dependent variable, and the independent variables are those in equation (1). We include year dummies for the pre-treatment period (i.e., 2010) and the post-treatment periods (i.e., 2012 and 2013), and omit the dummy (i.e., 2011) for the year before the actual treatment date (i.e., 2012). In addition, we interact these year dummies with TREAT. Untabulated results reinforce the validity of the parallel-trends assumption, as the coefficient on the interaction term TREAT $x 2010$ is statistically insignificant. We thank an anonymous reviewer for this suggestion.

27 Panel A of Table 2 is based on the matched sample. Note that matching eliminated previous significant covariate differences between the treatment and control firms. As Table OA.1 in the Online Appendix shows significant pre-matching differences between the treatment and control firms (particularly in the pre-treatment period), propensity-score matching achieves its main objective of covariate balance between the treatment and control observations. 
by -3.73 ; this difference is not significant ( $p$-value $=0.235$ ). Control firms' $\% E Q$ declines by 2.19; again, this difference is not significant ( $p$-value $=0.546)$. The difference-in-differences of interest, -1.54 , is significant at the $10 \%$ level ( $p$-value $=0.10$ ). Similarly, whereas treatment and control firms' changes in \%BONDS are not statistically significant, the difference-indifferences (3.03) is significant at the 5\% level ( $p$-value $=0.020)$. These findings provide initial support for $\mathrm{H}_{1}$, which predicts that treatment firms decrease (increase) \%EQ (\%BONDS) relative to control firms after the mandatory adoption of IAS 19R.

\section{TABLE 3 ABOUT HERE}

Panel B of Table 3 reports multivariate results. Whereas columns (1) and (2) present baseline results for equation (1), columns (3) and (4) introduce the experimental variables Post, TREAT, and Post $\mathrm{x}$ TREAT, and present the results of the main test of $\mathrm{H}_{1}{ }^{28}$ Results for the base model in column (1) show that $\% E Q$ is significantly associated as predicted with ownership structure $(F F$; coefficient $=0.14 ; z$-statistic $=2.13)$ and the funding levels of pension plans (Fund; coefficient $=-0.30 ; z$-statistic $=-2.80$ ). The adjusted $\mathrm{R}^{2}$ of $31.5 \%$ is above findings in prior literature (e.g., Rauh, 2009; Anantharaman \& Chuk, 2017). Turning to the results for \%BONDS, column (2) displays the expected negative association with ownership structure $(F F$; coefficient $=-0.26 ; z$-statistic $=-2.79)$, and an adjusted $\mathrm{R}^{2}$ of $29.0 \%$.

Column (3) presents the effect of the elimination of the corridor method on the percentage of equity securities in firms' pension plan assets $\left(\mathrm{H}_{1}\right)$. The main variable of interest highlighted in bold - is Post $\times$ TREAT, which captures the change in \%EQ after the introduction of IAS 19R that is unique to treatment firms (i.e., the difference-in-differences across the treatment and control firms). The coefficient on Post $\times$ TREAT is significant and negative, suggesting that, conditioning on the control variables, treatment firms on average reduce the percentage of equity investments by 2.46 percentage points $(z$-statistic $=-3.35)$ more than control firms after IAS 19R adoption. This effect is economically significant given the pretreatment level of $27.3 \%,{ }^{29}$ and supports $\mathrm{H}_{1}$. Turning to \%BONDS, column (4) shows a coefficient on Post $\times$ TREAT that is statistically significant and positive as expected (coefficient $=$

28 Table 3 reports difference-in-differences results based on the matched sample. Online Appendix Table OA.2 provides the results for the probit model used to match treatment and control firms. These results are robust to including \%EQ (contemporaneous and lagged) in the probit model as an additional explanatory variable (untabulated). We thank the reviewer for this suggestion. Difference-in-differences results without matching (untabulated) lead to the same inferences as those reported in Table 3. However, note that covariate balance is limited in the unmatched sample.

29 The pre-treatment difference between treatment and control firms is captured by TREAT, which is negative but not significantly different from zero (coefficient $=-1.36 ; z$-statistic $=-0.43$ ). 
4.61; z-statistic $=2.43$ ); it is also economically significant relative to the pre-treatment level of $48.3 \%$. Overall, results for both $\% E Q$ and $\% B O N D S$ are consistent with treatment firms adjusting their pension asset allocations more strongly than control firms upon IAS 19R adoption. This is consistent with the 'IAS $19 \mathrm{R}$ effect' of $\mathrm{H}_{1}$, which predicts that treatment firms attempt to counteract the increase in equity volatility expected under IAS 19R.

Panel C of Table 3 reports results for equation (3), testing $\mathrm{H}_{2}$. Recall $\mathrm{H}_{2}$ predicts that pension plan magnitude (Exp) and funding (Fund) moderate the IAS 19R effect on $\% E Q$ and $\% B O N D S$. Accordingly, columns (1) and (3) present results for $\% E Q$, whereas columns (2) and (4) focus on \%BONDS. The main coefficient of interest in all columns - highlighted in bold - is that on the three-way interaction Post $\times$ TREAT $\times$ PP_CHAR (where PP_CHAR is either Exp or Fund), which captures incremental changes in \%EQ or \%BONDS after IAS 19R adoption unique to treatment firms with higher levels of Exp (i.e., relatively larger pension plans) or Fund (i.e., relatively better funded pension plans), respectively.

Similar to the results in Table 3 Panel B, in column (1), the coefficient on Post $\times$ TREAT is negative and highly significant (coefficient $=-6.70 ; z$-statistic $=-5.69)$. The coefficient on Post $\times$ TREAT $\times$ Exp is significantly positive (coefficient $=0.16$; $z$-statistic $=4.36$ ), indicating that exposure to larger pension plans attenuates treatment firms' tendency to shift pension assets out of equities. Column (2) displays results consistent with this insight. The significantly negative coefficient on Post $\times$ TREAT $\times$ Exp with $\%$ BONDS as the dependent variable (coefficient $=-0.17 ; z$-statistic $=-3.24$ ) suggests that exposure to larger pension plans also dampens treatment firms' proclivity to increase their bond investments relative to control firms upon IAS 19R adoption. ${ }^{30}$ Overall, whereas these attenuation effects may not appear economically massive, they reflect the change in the dependent variable associated with a one-percentage-point change in the independent variable. Results are similar when we consider Fund as a pension plan characteristic, as evidenced by a highly significant positive (negative) coefficient on Post $\times$ TREAT $\times$ Fund for $\% E Q(\% B O N D S)$ as the dependent variable $(\% E Q:$ coefficient $=0.08 ; z$-statistic $=3.49 ; \% B O N D S:$ coefficient $=-0.14$; $z$-statistic $=-2.26) .{ }^{31}$ The results on $F U N D$ is negatively significant whereas other control

30 These results also hold when we calculate Exp as defined benefit obligation (rather than by pension assets, as in the main analyses) divided by the book value of equity, to capture the exposure of firms' book value of equity to the size of pension plans for firms with relatively low pension assets but - at the same time - relatively high pension obligations. Untabulated results are consistent with the findings reported in the main analysis.

31 In addition to the Table 3 analyses, we implement the test of $\mathrm{H}_{2}$ by estimating equation (3) after splitting the sample based on the median value of PP_CHAR, which is either Exp or Fund. Results reported in Table OA.3 in the Online Appendix are consistent with those reported in Table 3. Specifically, we find significantly negative 
variables are not significant, consistent with the results reported by Anantharaman and Chuk (2017). ${ }^{3233}$

Taken together, the main tests support the prediction that firms adjust their pension asset allocations to mitigate pension-induced equity volatility when an accounting change (i.e., the mandatory adoption of IAS 19R) eliminates a previously available smoothing device $\left(\mathrm{H}_{1}\right)$. We obtain this result using a difference-in-differences research design, which benchmarks treatment firms' average response to trends exhibited by a group of control firms unaffected by that accounting change. We also find evidence for $\mathrm{H}_{2}$, under which we expect that pension plan characteristics - specifically magnitude (Exp) and funding status (Fund) - moderate the IAS 19R effect on the pension asset allocation. Interpreted in the light of our evidence from interviews and firms' public statements, results indicate that IAS 19R prompts firms to take action to mitigate IAS 19R-induced equity volatility. One instrument of choice for achieving this aim is to rebalance the pension asset allocation away from riskier assets. Firms with relatively larger and better funded pension plans exhibit this behavior to a lesser degree - presumably because they supplement, or even prioritize, other de-risking strategies (which are more difficult for us to observe), such as derivative hedging ${ }^{34}$, settlements or curtailments, over the reallocation of pension assets out of equities and into bonds. ${ }^{35}$

\subsection{Alternative Analyses: Disentangling the "IAS 19R Effect"}

This section complements the main analysis of section 4.2 by exploring an alternative channel through which adoption of IAS 19R could affect treatment firms' pension asset allocations. As explained in section 2.1, IAS 19R not only eliminates the corridor method in favor of the OCI method (the 'OCI effect'), but it also changes the calculation of net periodic pension cost

(positive) coefficients on POST x TREAT for firms with below-median PP_CHAR where the dependent variable is \%EQ $(\% B O N D S)$. In contrast, coefficients on POST $\times$ TREAT are insignificant for firms with above-median PP_CHAR (except for PP_CHAR = Fund in the \%BONDS model).

32 These results suggest that treatment and control firms are closely balanced along these variables.

33 We repeated the analysis reported in Table 3 after including year fixed effects and industry-by-year fixed effects, and the results are qualitatively similar.

34 Due to lack of granularity in firms' pension asset disclosures, we are unable to test explicitly whether treatment firms adjust their derivatives-based pension de-risking activities around the adoption of IAS 19R. Inspection of pension footnotes indicates that only a small portion of our sample discloses the proportion of pension assets representing derivatives. Even for those firms, the specific types of derivatives, their attributes, and whether they are intended for pension de-risking, are ultimately opaque.

35 Overall, these findings are robust to including SHIFT, an indicator variable equal to one if firm $i$ terminates or freezes existing defined benefit pension plans, or transfers risk to insurance companies, in year $t$, and zero otherwise, as an additional control variable, following Amir et al. (2010). However, the three-way interactions are insignificant when PP_CHAR is Fund (refer to section 4.4.4). The purpose of including SHIFT is to control for firms altering or closing their defined benefit pension plans as an alternative means of mitigating the increase in pension-induced equity volatility brought about by IAS $19 \mathrm{R}$. 
by requiring that the expected return on plan assets be based on the discount rate. This 'ERR effect' could trigger pension asset rebalancing, e.g., through managers losing their incentive to invest in risky pension assets as a justification for inflated ERRs and higher earnings (e.g., Bergstresser et al., 2006; Anantharaman \& Chuk, 2017).

However, such asset allocation shifting should only arise where it is of sufficient magnitude to matter, i.e., (1) where plan assets tend to be larger relative to DBOs (generating larger returns, ceteris paribus), and (2) where expected rate of return assumptions tend to deviate more from discount rate assumptions. Regarding (1), German firms traditionally employ unfunded defined benefit plans (i.e., plans with no plan assets) as well as funded defined benefit plans. Consequently, the pre-treatment median funded status (i.e., fair value of plan assets as a percentage of the DBO) of the German treatment group is 62.8\% (Table OA.5 in the Online Appendix), compared to $80.2 \%$ for Anantharaman and Chuk's (their Panel A of Table 2) Canadian treatment group. Regarding (2), we have compared pre-treatment ERRs and discount rates for the German and Canadian treatment groups. (Recall that separate ERRs are no longer available under IAS 19R post-treatment.) Whereas German treatment firms' median ERR is $5.21 \%$, Anantharaman and Chuk's (their Panel A of Table 2) Canadian treatment firms use a median ERR of 6.27\%; at the same time, median discount rates are nearly equal (4.69 versus 4.50\%). The higher median deviations between ERRs and discount rates for Canadian firms suggest that the expected ERR-induced earnings impact of IAS 19R is larger for Canadian firms. We view these structural differences (1) and (2) between Canadian and German pension plans as indicators that any ERR effect in Germany will differ from that documented by Anantharaman and Chuk (2017) for Canada.

To isolate the ERR effect, we use treatment firms that switch from the OCI method under IAS 19 (asset returns based on expected rate assumption) to that under IAS 19R (asset returns based on discount rate). This treatment group is provided by German IAS 19R adopters that had been voluntarily applying the OCI method under the original IAS 19 and now adopt IAS 19R (i.e., the previous control group in the main tests; see section 4.2). The control group here consists of U.S. firms reporting under SFAS 158; these firms apply a stable OCI method (with asset returns calculated using firms' expected rate of return assumptions) throughout the analysis period. This test effectively isolates the ERR effect by holding firms' application of the OCI method constant while varying the expected rate of return method. We select U.S. control observations by downloading data for U.S. firms sponsoring defined benefit pension plans between 2010 and 2013, i.e., the same time period used in the main analysis reported in Table 3 . We then apply a propensity score matching procedure that 
mirrors the one used for the main analyses in section 4.2; it yields 164 treatment observations and an equal number of matched control observations. ${ }^{36}$ Summary statistics indicate covariate balance in the pre-treatment period, the only exception being U.S. firms' higher percentage of free float $(F F)$. German and U.S. firms further differ in their pension asset allocations, with U.S. firms having significantly higher (lower) $\% E Q(\% B O N D S) .{ }^{37,38}$

Multivariate regression results are reported in Table 4, which mirrors the layout of Table 3 Panel C. Regarding the pension asset allocation to equities (\%EQ), column (1) indicates no significant effect of IAS $19 \mathrm{R}$ on treatment firms when the partitioning variable captures relative pension plan size (i.e., PP_CHAR $=E x p$ ). However, when PP_CHAR $=$ Fund in Column (3), treatment firms with lower funded status significantly increase their $\% E Q$ relative to control firms after mandatory IAS 19R adoption (coefficient on Post $\times$ TREAT $=7.00$; $z$-statistic $=2.75$ ). That effect is slightly attenuated for firms with high Fund, evidenced by a significantly negative coefficient on Post $\times$ TREAT $\times$ Fund $(-0.10 ; z$-statistic $=-2.90)$.

\section{TABLE 4 ABOUT HERE}

Turning to the pension asset allocation to bonds (\%BONDS), column (2) shows that treatment firms with small pension plans (i.e., low Exp) strongly and significantly decrease their \%BONDS relative to control firms after mandatory IAS 19R adoption (coefficient on Post $\times$ TREAT $=-11.01 ; z$-statistic $=-7.01)$. That effect also is slightly attenuated for firms with high Exp (significantly positive coefficient on Post $\times$ TREAT $\times$ Exp of 0.12; $z$-statistic $=3.32$ ). In column (4), we find a similar relation for Fund as the conditioning pension plan characteristic, with the coefficient on Post $\times$ TREAT negative and highly significant $(-12.08$; $z$-statistic $=-5.59)$; however, no significant incremental effect of high funding is observed (insignificant coefficient on Post $\times$ TREAT $\times$ Fund) ${ }^{39}$

Recall these alternative analyses repeat the main test for a setting in which only the calculation of pension expense changes (the 'ERR effect'), with no corresponding change to the accounting for actuarial gains and losses (the 'OCI effect'). In this setting, which isolates the

36 For sample selection details, refer to Table OA.4 in the Online Appendix.

37 Full summary statistics are reported in Table OA.5 in the Online Appendix.

38 Untabulated results for $\mathrm{H}_{1}$ suggest that Post $\times$ TREAT is insignificant in the $\% E Q$ model, whereas it is negatively significant in the \%BONDS model.

39 We repeated the analysis reported in Table 4 after including year fixed effects and industry-by-year fixed effects, and the results are qualitatively similar, with the exception of the coefficient on Post $\times$ TREAT, which is positive and marginally significant in the $\% E Q$ model in column (1) when including industry-by-year fixed effects. 
ERR effect, ${ }^{40}$ any significant rebalancing in pension asset allocations should not be due to the OCI effect. Indeed, the results described in this section show a pattern of pension asset rebalancing distinct from that found in the main tests. Specifically, the ERR effect documented here is consistent with treatment firms strongly shifting out of bonds relative to control firms. This contradicts $\mathrm{H}_{1}$ and our main finding reported in section 4.2; it also contrasts with what Anantharaman and Chuk (2017) finds for Canadian firms. It is not obvious why these differences emerge. Our discussion and descriptive evidence presented earlier in this section indicate that German and Canadian pension plans differ in terms of pre-IAS 19R funded status and ERR assumptions. In addition, in contrast to the study by Anantharaman and Chuk (2017) the spread between the ERR and the discount rate is much smaller German firms, which may partly explain the divergent findings. Additional factors underlying diverging German versus Canadian ERR effects could include different sample compositions and management incentives. $^{41}$

\subsection{Robustness Tests}

\subsubsection{Alternative Measurement Windows}

The main analyses use four fiscal years, two in the pre- (2010 and 2011) and two in posttreatment period (2012 and 2013), with the beginning of 2012 as the treatment date. We expect this window to be sufficiently long for firms to adjust their pension asset allocations, and simultaneously short enough to minimize the risk of capturing confounding factors that affect the treatment and control groups differently. In this section, we vary the measurement window in two ways to assess the robustness of our identification strategy. First, to account for the possibility that firms require more time to reallocate their pension assets, we increase the number of post-treatment periods to three, by including 2014. Second, we extend the pretreatment period by one year, yielding the five-year window 2009-2013.

Panel A of Table OA.6 presents the results for the 2010-2014 window, whereas Panel B presents the results for the 2009-2013 window. In both panels, columns (1) and (2) report re-

40 Note this test is largely comparable with the main test in Anantharaman and Chuk (2017) - with one exception: Whereas our treatment group in this test consists solely of OCI method firms, Anantharaman and Chuk's (2017) main test includes corridor firms in the treatment group, effectively mixing the ERR and OCI effects. Anantharaman and Chuk (2017) include an indicator variable, e.g., CORRIDOR, to control for the alternative options for recognizing actuarial gains or losses under IAS 19; they note that the CORRIDOR indicator variable is insignificant, 'suggesting that any balance sheet effects for firms using the corridor method for balance sheet recognition prior to IAS 19R are not substantial' (p. 28).

41 Furthermore, Anantharaman and Chuk's (2017) research design choices vary to some extent from ours, including in the choice of matching algorithm, measurement windows and control variables. 
sults for $\% E Q$ and $\% B O N D S$ where $P P_{-} C H A R=E x p$, and columns (3) and (4) repeat the analyses for PP_CHAR $=$ Fund . When $\% E Q$ is the dependent variable, results are directionally consistent with, albeit somewhat weaker than, the main tests reported in section 4.2. Specifically, no significant effects obtain when Fund is the pension plan characteristic examined. These weaker results are to some extent expected, as lengthening the measurement windows around the treatment date decreases test power. When \%BONDS is the dependent variable, results are consistent with the main tests, with coefficients on Post $\times$ TREAT positive and significant across all specifications. Also, coefficients on Post $\times$ TREAT $\times$ Exp are negatively significant, again consistent with the results reported in the main analysis, with the exception of results reported in column (2) of Panel B. Overall, these results suggest that firms are on average able to adjust their pension asset allocations within two years after the publication of IAS 19R.

\subsubsection{Alternative Treatment Dates and Placebo Tests}

As discussed in section 3.1.2, we expect the treatment date (beginning of 2012) to capture the point in time at which treatment firms start adjusting to the requirements of IAS 19R. To examine alternative treatment dates, we conduct the following two sets of additional tests. First, we shift the treatment date to the beginning of 2013 (IAS 19R's official effective date; see Figure 1), yielding a four-year window (2011-2014). We do this because firms' pension asset rebalancing might be a process still ongoing after 2013. Second, as a placebo test, we repeat the main tests for periods during which no treatment effect is expected. Finding no significantly negative coefficient on Post $x$ TREAT in the period before mandatory IAS 19R adoption decreases the likelihood that the difference-in-differences is a chance finding, increasing our confidence in the parallel-trends assumption underlying the main tests. We therefore reestimate the main analysis for the period 2007-2010 and falsely assume a treatment three years earlier, in 2009. Failing to find significant differences between the treatment and control groups would support the parallel trend assumption. ${ }^{42}$

Results for 2013 as the treatment date are reported in Panel C of Table OA.6. Columns (1) and (3) report the results for $\% E Q$ and columns (2) and (4) report the results for $\% B O N D S$. The coefficient on Post $x$ TREAT is negatively significant in column (1), when

42 In untabulated analyses, we conduct another robustness test, where, we define 2009-2010 as the pre-treatment period and 2013-2014 as the post-treatment period. Overall, the results are very similar (with coefficients slightly larger) to those reported in the main analysis when $P P_{-} C H A R=\operatorname{Exp}$. However, the coefficients of interest are only significant for PP_CHAR = Fund in the \%BONDS specification. 
Exp is the PP_CHAR examined; the Post $\times$ TREAT $\times$ Exp coefficient is positively significant. These results are consistent with those reported in the main analysis. However, the variables of interest are insignificant when Fund is the PP_CHAR in column (3). As expected and consistent with the results reported in the main analysis, the coefficient on Post $x$ TREAT is positive and significant when \%BONDS is the dependent variable in columns (2) and (4). However, Post $\times$ TREAT $\times$ Exp and Post $\times$ TREAT $\times$ Fund are statistically insignificant.

Panel D of Table OA.6 reports the results when assuming a placebo treatment date in 2009. Again, columns (1) and (2) report the results for \%EQ and \%BONDS when Exp is the PP_CHAR examined, while columns (3) and (4) report the results for $\% E Q$ and $\% B O N D S$ when Fund is the PP_CHAR examined. The coefficients on Post $\times$ TREAT, Post $\times$ TREAT $\times$ PP_CHAR are insignificant when $\% E Q$ is the dependent variable and when $P P \_C H A R$ is Exp and Fund. This is expected, as there is no treatment that would cause $\% E Q$ to diverge between the treatment and control groups. Unexpectedly, the Post $\times$ TREAT coefficient is positively significant when $\% B O N D S$ is the dependent variable in column (2), and Post $\times$ TREAT $\times$ Exp is negatively significant. Overall, however, results of this falsification test support our inferences from the main analyses that the difference-in-differences in pension asset allocations observed in 2012 are likely caused by IAS 19R, rather than some alternative event occurring earlier.

\subsubsection{Alternative Matching Procedures}

In the main analysis, we used nearest-neighbor matching without replacement to match treatment and control firms. As a robustness test, we apply caliper matching without replacement. In this context, we follow prior literature and set the caliper equal to $20 \%$ of the standard deviation of the estimated propensity score (Cochran \& Rubin, 1973; D'Agostino, 1998). This matching procedure reduces the sample size to 144 firm-year observations.

The results are reported in Table OA.7 in the Online Appendix. Columns (1) and (2) report the results for $\% E Q$ and $\% B O N D S$ when Exp is the PP_CHAR examined, while columns (3) and (4) report the results for \%EQ and \%BONDS when Fund is the PP_CHAR examined. When $\% E Q$ is the dependent variable, the Post $x$ TREAT coefficient is negatively significant in columns (1) and (3) and the Post $\times$ TREAT $\times \operatorname{Exp}$ coefficient is positively significant in column (1), consistent with the results reported in the main analysis. However, the Post $\times$ TREAT $\times$ Fund coefficient in column (3) is insignificant. When \%BONDS is the dependent variable Post $\times$ TREAT is positively significant and Post $\times$ TREAT $\times$ PP_CHAR is 
negatively significant across all specifications. Overall, these results suggest that the main findings are robust to this alternative matching procedure.

\subsubsection{Additional Control Variables}

In this section, we test whether the main findings are robust to additional control variables. Regarding additional control variables, we include the square of the funding ratio $\left(F u n d^{2}\right)$, the square of percentage of free float $\left(F F^{2}\right)$, market returns (Market Returns), the payout ratio (Payout Ratio) and a variable capturing terminations and freezes of defined benefit plans as well as transfers of risk to insurance companies (SHIFT). Fund ${ }^{2}$ captures a possible non-linear relation between Fund and \%EQ. As described in section 3.1, this relation is suggested by theoretical research for firms with low levels of funding, as managers have incentive to increase $\% E Q$ to benefit from the increase in risk (Harrison \& Sharpe, 1983; Rauh, 2009). Similarly, the square of $F F$ controls for a non-linear relation between ownership structure and $\% E Q$. Prior research by Faßhauer et al. (2011) finds that very low and very high ownership concentrations explain the choice between the corridor and OCI methods. However, we do not include these variables in the main analysis because of potential multicollinearity issues. ${ }^{43}$ Further, we include a proxy for stock market performance (Market Returns) as an additional control variable. Positive (negative) market returns increase (decrease) the value of equity investments. If firms do not rebalance their portfolios, $\% E Q$ varies with market returns. Consistent with Anantharaman and Chuk (2017), we measure market returns by the returns to the S\&P Global Broad Market Index for equities, which measures global stock market performance. Over the sample period, Market Returns is positive for all years except 2011. Following Anantharaman and Chuk (2017), we include the dividend payout ratio, as firms which typically pay dividends have stronger incentives to minimize volatility in order to ensure that they will have sufficient cash flows to make dividend payments. Finally, we include SHIFT, following Amir et al. (2010).

Table OA.8 in the Online Appendix presents results of including these additional control variables. Columns (1) and (2) report the results for \%EQ and \%BONDS when Exp is the $P P \_C H A R$ examined, while columns (3) and (4) report the results for $\% E Q$ and $\% B O N D S$ when Fund is the PP_CHAR examined. The coefficient on Post $\times$ TREAT is significantly negative when $\% E Q$ is the dependent variable in column (1) and positive for \%BONDS in

43 Pearson and Spearman correlation coefficients between Fund and Fund ${ }^{2}$ are significant and above 0.96 and those between $F F$ and $F F^{2}$ are significant and above 0.99 . 
columns (2) and (4), consistent with the results reported in the main analysis. The Post $\times$ TREAT $\times$ Exp and Post $\times$ TREAT $\times$ Fund coefficients for $\% E Q$ and $\%$ BONDS are significantly positive and negative respectively in columns (1) and (2). ${ }^{44}$ Overall, the findings generally support results of the main analyses in Table 3.

\subsubsection{Subsample Analyses}

Finally, we analyze subsamples excluding firms with high proportions of 'other (pension) assets' to address concerns regarding the characteristics of the pension asset category of 'other assets' and in particular the opacity of this asset class. We find an increase in the median \%OTHER from $15.2 \%$ in the pre-IAS $19 \mathrm{R}$ period to $18.1 \%$ in the post-IAS $19 \mathrm{R}$ period for the main sample. Föhrenbach, Glaum, and Keller (2015) raises the concern that the aggregation of 'other assets' into a residual category loses information needed to evaluate the risk characteristics and volatility of these assets. For example, 'other assets' includes both insurance contracts and shares in hedge funds, which we expect to have different risk properties. In fact, assuming that lower levels of pension assets invested into equities lead to lower levels of volatility depends on the volatility characteristics of other asset classes. To address the impact of the inclusion of 'other assets' in the main analysis, we carry out a robustness test excluding observations for which the category 'other assets' is $25 \%$ or greater.

The results are reported in Table OA.9 in the Online Appendix. Columns (1) and (2) report the results for $\% E Q$ and $\% B O N D S$ when Exp is the PP_CHAR examined, while columns (3) and (4) report the results for $\% E Q$ and $\% B O N D S$ when Fund is the PP_CHAR examined. The coefficient on Post $\times$ TREAT is significantly negative (positive) for $\% E Q$ and $\% B O N D S$; the coefficient on Post $\times$ TREAT $\times \operatorname{Exp}($ Post $\times$ TREAT $\times$ Fund $)$ is positive (negative) when $\% E Q(\% B O N D S)$ is the dependent variable, consistent with the results reported in the main analysis. Inferences are similar when we exclude observations for which the category 'other assets' is $20 \%$ or greater (untabulated). In particular, the coefficient on POST $x$ TREAT is negative (positive) when the dependent variable is \%EQ (\%BONDS); however, the coefficient on POST $\times$ TREAT $\times$ PP_CHAR is statistically insignificant, possibly due to reduced sample size and hence lower test power. Overall, these results suggest that the findings of the main analysis are not driven by firms that invest pension assets in this opaque asset category; they

${ }^{44}$ However, the Post $\times$ TREAT and Post $\times$ TREAT $\times$ Fund coefficients are insignificant in column (3) where PP_CHAR is Fund. The Post $\times$ TREAT $\times$ Fund is also insignificant in column (4). Given the high correlation between Fund and $F u n d^{2}$, this regression specification suffers from multicollinearity. 
indicate that there was no massive substitution effect in the asset allocation between equities and other assets.

\section{$5 \quad$ Conclusion}

This paper examines the 'real' effects of a change in accounting standards on a specific type of investment decision: firms' allocation of pension assets into asset classes with different risk and return profiles. Extant literature identifies the elimination of the expected rate of return (Anantharaman \& Chuk, 2017), the risk of recognizing an additional minimum pension liability (Amir \& Benartzi, 1999), and the introduction of IAS 19 (Amir et al., 2010) as examples of accounting standards affecting pension asset allocations. We advance this stream of research by examining whether the elimination of the corridor method of recognizing actuarial pension gains and losses affects the allocation of firms' pension assets.

To examine this research question, we use the mandatory change from IAS 19 to IAS 19R. The latter requires immediate recognition of actuarial gains and losses in other comprehensive income (OCI method), removing a previously available smoothing device. We apply a difference-in-differences research design that compares treatment firms affected by the accounting change to control firms that are unaffected. This test design allows us to approach identification of the causal effect of mandatory IAS 19R adoption on firms' pension asset allocations to the extent feasible in an observational study.

We predict and find that treatment firms shift their pension assets from equities into bonds relative to matched control firms, consistent with firms rebalancing their pension asset allocations to mitigate a potential increase in pension-induced equity volatility. Further, we find that this rebalancing is attenuated for firms with larger pension plans and higher funding levels. Results are robust to alternative control groups, varying measurement periods and alternative model specifications.

We further undertake to disentangle two distinct and potentially contradicting effects of IAS 19R on firms' pension asset allocations: the OCI effect and the ERR effect. Whereas the main tests inevitably mix both effects, they suggest - consistent with predictions - that the OCI effect is strong and driven by firms' concerns about IAS 19R-induced equity volatility. In contrast, the additional analysis using German OCI firms and a U.S. control sample yields results that are inconsistent with our predictions and concurrent evidence from the Canadian setting (Anantharaman \& Chuk, 2017). Future research can exploit settings that allow clean isolation of the OCI effect. Such settings require holding the ERR method constant while varying the OCI method. One such setting consists of corridor-method firms adopting the "old" 
OCI method under IAS 19 in the pre-IAS 19R period. Control samples would be given by corridor-method or OCI-method firms staying with their respective methods throughout the analysis period. While we attempted such tests in our setting, data constraints (i.e., a small number of treatment firms) preclude them.

Our results are subject to the following limitations. First, the single-country results may not generalize to other countries. Second, we do not explicitly test implications of Anantharaman and Lee (2014), which suggests manager-specific incentives as further determinant of pension asset allocations. However, to the extent that these incentives are time-invariant, our difference-in-differences research design controls for them. Third, propensity score matching requires close matches, thus reducing the sample and the power of the tests. Fourth, the matched-sample difference-in-differences design addresses omitted variable bias to the extent feasible in the present setting; however, lingering self-selection concerns cannot be entirely ruled out. Finally, a lack of detailed disclosure requirements inhibits our ability to discern the asset classes (except bonds) that firms shift into when reducing their exposure to equities. Specifically, a large and opaque category 'other assets' (which can contain low-risk assets such as cash as well as high-risk ones such as hedge fund shares) likely captures some of these movements (see Föhrenbach et al., 2015). Finer disaggregation would render plan asset disclosures more useful for many purposes, including risk assessment and academic research.

This study complements prior literature on the determinants of pension asset allocations. In a broader context, we add to the literature on the 'real' effects of accounting by showing that managers alter their pension assets investment strategies in response to an accounting change that increases expected pension-induced equity volatility. These insights are relevant to financial reporting standard setters, as they elucidate the behavioral consequences of accounting standards - in particular, of those that narrow firms' set of accounting choices and of those that increase expected financial statement volatility. Finally, our findings suggest that accounting for corporate pension plans affects the allocation of pension assets and thereby their riskiness. Such shifts may or may not be intended or desired by the standard setter. Future research could explore the consequences of these behavioral shifts for the firms' stakeholders, and how these effects vary with the extent of home bias in firms' asset allocation decisions. 


\section{References}

Agrawal, A. K. (2013). The impact of investor protection law on corporate policy and performance: Evidence from the blue sky laws. Journal of Financial Economics, 107(2), 417-435.

Amir, E., \& Benartzi, S. (1999). Accounting recognition and the determinants of pension asset allocation. Journal of Accounting, Auditing \& Finance, 14(3), 321-343.

Amir, E., Guan, Y., \& Oswald, D. (2010). The effect of pension accounting on corporate pension asset allocation. Review of Accounting Studies, 15(2), 345-366.

Anantharaman, D., \& Chuk, E. C. (2017). The economic consequences of accounting standards: Evidence from risk-taking in pension plans. The Accounting Review. Advance online publication.

Anantharaman, D., \& Lee, Y. G. (2014). Managerial risk taking incentives and corporate pension policy. Journal of Financial Economics, 111(2), 328-351.

Bader, L. N. (1991). The Financial Executive's guide to pension plans. New York: Salomon Brothers.

Bao, M. X., Billett, M. T., Smith, D. B., \& Unlu, E. (2018). Does incremental other comprehensive income (OCI) volatility affect the cost of debt, capital structure and credit ratings? (Working Paper). University of New Hampshire, Indiana University, and University of Nebraska at Lincoln.

Beaudoin, C., Chandar, N., \& Werner, E. M. (2010). Are potential effets of SFAS 158 associated with firms' decisions to freeze their defined benefit pension plans? Review of Accounting and Finance, 9(4), 424-451.

Bergstresser, D., Desai, M., \& Rauh, J. (2006). Earnings manipulation, pension assumptions, and managerial investment decisions. The Quarterly Journal of Economics, 121(1), 157-195.

Bikker, J. A., Broeders, D. W. G. A., Hollanders, D. A., \& Ponds, E. H. M. (2012). Pension funds' asset allocation and participant age: A test of the life-cycle model. The Journal of Risk and Insurance, 79(3), 595-618.

Chava, S., \& Purnanandam, A. (2010). Is default risk negatively related to stock returns? Review of Financial Studies, 23(6), 2523-2559.

Choudhary, P., Rajgopal, S., \& Venkatachalam, M. (2009). Accelerated vesting of employee stock options in anticipation of FAS 123-R. Journal of Accounting Research, 47(1), 105146.

Chuk, E. C. (2013). Economic consequences of mandated accounting disclosures: Evidence from pension accounting standards. The Accounting Review, 88(2), 395-427.

Cocco, J. F., Gomes, F. J., \& Maenhout, P. J. (2005). Consumption and portfolio choice over the life cycle. Review of Financial Studies, 18(2), 491-533.

Cochran, W. G., \& Rubin, D. B. (1973). Controlling bias in observational studies: A review. Sankhya: The Indian Journal of Statistics, Series A, 35(4), 417-446. 
D'Agostino, R. B. (1998). Propensity score methods for bias reduction in the comparison of a treatment to a non-randomized control group. Statistics in Medicine, 17, 2265-2281.

Deutsche Lufthansa AG (2012). Annual Report 2012. Cologne.

Ernst \& Young (2011). Implementing the 2011 revisions to employee benefits (www.ey.com).

Fama, E. F., \& French, K. R. (1993). Common risk factors in the returns on stocks and bonds. Journal of Financial Economics, 33(1), 3-56.

Faßhauer, J. D., Glaum, M., Keller, T., \& Street, D. L. (2011). Erfassungsmethoden für versicherungsmathematische Gewinne und Verluste nach IAS 19: Motive der Wahlrechtsentscheidung europäischer Unternehmen. Zeitschrift für betriebswirtschaftliche Forschung 63(8), 774-809.

Föhrenbach, L., Glaum, M., \& Keller, T. (2015). Pension plan asset allocation in France, Germany and the UK: The growing importance of "other assets" (Working paper). WHU - Otto Beisheim School of Management.

Glaum, M. (2009). Pension accounting and research: A review. Accounting and Business Research, 39(3), 273-311.

Glaum, M., Keller, T., \& Street, D.L. (2018). Discretionary accounting choices: The case of IAS 19 pension accounting. Accounting and Business Research, 48(2), 139-170.

Gow, I. D., Larcker, D. F., \& Reiss, P. C. (2016). Causal inference in accounting research. Journal of Accounting Research, 54(2), 477-523.

Graham, J. R., Harvey, C., \& Rajgopal, S. (2005). The economic implications of corporate financial reporting. Journal of Accounting and Economics, 40(1-3), 3-73.

Harrison, J. M., \& Sharpe, W. F. (1983). Optimal funding and asset allocation rules for definedbenefit pension plans. In Z. Bodie \& J. Shoven (Eds.), Financial Aspects of the U.S. Pension System. Chicago, IL: University of Chicago Press.

Hitz, J.-M., Ernstberger, J., \& Stich, M. (2012). Enforcement of accounting standards in Europe: Capital market-based evidence for the two-tier mechanism in Germany. European Accounting Review, 21(2), 253-281.

IFRS Foundation (2011). International Accounting Standard 19 Employee Benefits.

IFRS Foundation (2010). Exposure draft Defined Benefit plans: Proposed amendments to IAS 19.

Jin, L., Merton, R. C., \& Bodie, Z. (2006). Do a firm's equity returns reflect the risk of its pension plan? Journal of Financial Economics, 81(1), 1-26.

Kanodia, C. (2007). Accounting disclosure and real effects. Foundations and Trends in Accounting, 1(3), 167-258.

Kiosse, P. V., \& Peasnell, K. (2009). Have changes in pension accounting changed pension provision? A review of the evidence. Accounting \& Business Research, 39(3), 255-267.

Lennox, C. S., Francis, J. R., \& Wang, Z. (2012). Selection models in accounting research. The Accounting Review, 87(2), 589-616. 
Leuz, C., \& Wysocki, P. D. (2016). The economics of disclosure and financial reporting regulation: Evidence and suggestions for future research. Journal of Accounting Research, 54(2) 525-622.

Mashruwala, S. (2008). Does smoothing in pension accounting encourage equity investment in corporate pension plans? Evidence from the UK (Working Paper). Baruch CollegeCUNY.

Mitra, G., \& Medova, E. (2010). Asset and liability management/liability-driven investment for pension funds. Journal of Asset Management, 11(2-3), 71-72.

Morais, A.(2010). Actuarial gains and losses: The determinants of the accounting method. Pacific Accounting Review, 22(1), 42-56.

Rauh, J. D. (2009). Risk shifting versus risk management: Investment policy in corporate pension plans. Review of Financial Studies, 22(7), 2687-2733.

Roberts, M. R., \& Whited, T. M. (2013). Chapter 7 - Endogeneity in empirical corporate finance. Handbook of the Economics of Finance, 2(Part A), 493-572.

Rosenbaum, P. R. (2010). Design of observational studies. New York, NY: Springer.

Stracke, C. (2013). Pension liabilities - Time to get real. Pimco Viewpoint, 1-4.

Sundaresan, S., \& Zapatero, F. (1997). Valuation, optimal asset allocation and retirement incentives of pension plans. Review of Financial Studies, 10(3), 631-660.

Tepper, I., \& Affleck, A. R. P. (1974). Pension plan liabilities and corporate financial strategies. Journal of Finance, 29(5), 1549-1564.

Watts, R. L., \& Zimmerman, J. L. (1986). Positive accounting theory. Englewood Cliffs, NJ: Prentice-Hall.

Zhang, H. (2009). Effect of derivative accounting rules on corporate risk-management behavior. Journal of Accounting and Economics, 47(3), 244-264. 
Appendix A. Variable definitions

$\% E Q_{i t} \quad$ Percentage of equity investments, equal to pension assets allocated to equity securities of firm $i$ for year $t$, divided by firm $i$ 's total pension assets of year $t$, all measured at the end of fiscal year $t$ (sources: hand-collection, Worldscope data item 18807).

$\% B O N D S_{i t} \quad$ Percentage of bond investments, equal to pension assets allocated to fixedincome securities of firm $i$ for year $t$, divided by firm $i$ 's total pension assets of year $t$, all measured at the end of fiscal year $t$ (sources: hand-collection, Worldscope data item 18807).

$\%$ Percentage of other investments, equal to pension assets allocated to other assets of firm $i$ for year $t$, divided by firm $i$ 's total pension assets of year $t$, all measured at the end of fiscal year $t$ (sources: hand-collection, Worldscope data item 18807).

$\%$ PROPERTY ${ }_{i t}$ Percentage of property investments, equal to pension assets allocated to real estate property of firm $i$ for year $t$, divided by firm $i$ 's total pension assets of year $t$, all measured at the end of fiscal year $t$ (sources: hand-collection, Worldscope data item 18807).

TREAT $_{i} \quad$ Indicator variable equal to 1 if firm $i$ is a treatment firm, i.e., recognizes actuarial gains and losses under the corridor method in 2012, and 0 if firm $i$ uses the OCI method in 2012 (source: hand-collection).

Post $_{i t} \quad$ Indicator variable equal to 1 for post-treatment periods, beginning in 2012, and 0 for pre-treatment periods.

Lev $v_{i t} \quad$ Leverage ratio of firm $i$ for year $t$, equal to total liabilities of firm $i$, divided by firm $i$ 's total assets, both measured at the end of fiscal year $t$ (source: Worldscope data items 03351, 02999).

$F F_{i t} \quad$ Percentage of free float of firm $i$ for year $t$, equal to the number of shares in free float of firm $i$, divided by firm $i$ 's total number of shares multiplied by 100 , both measured at the end of fiscal year $t$ (source: Worldscope data item noshff).

Size $e_{i t} \quad$ Natural logarithm of the market value of equity of firm $i$, measured at the end of fiscal year $t$ (source: Worldscope data item 08001).

$S D C F_{i t} \quad$ Standard deviation of operating cash flows of firm $i$ for year $t$, equal to the natural logarithm of the standard deviation of operating cash flows over the past 4 years of firm $i$, divided by firm $i$ 's book value of equity, all measured at the end of fiscal year $t$ (source: Worldscope data items 04860, 03501).

Fund $_{i t} \quad$ Pension funding ratio of firm $i$ for year $t$, equal to external pension assets of firm $i$, divided by firm $i$ 's overall defined benefit obligations multiplied by 100 , both measured at the end of fiscal year $t$ (sources: hand-collection, Worldscope data items 18807, 18809). 
Horizon $_{i t} \quad$ Investment horizon of pension assets, equal to the natural logarithm of the ratio of defined benefit obligations of firm $i$, divided by firm $i$ 's current service cost, both measured at the end of fiscal year $t$ (source: Worldscope data items 18809, 18811).

$\operatorname{Exp}_{i t} \quad$ Exposure of firm $i$ 's book value of equity to the size of a pension plan for year $t$, equal to pension assets of firm $i$, divided by firm $i$ 's book value of equity multiplied by 100 , both measured at the end of fiscal year $t$ (source: Worldscope data items 18807, 03501).

Ind $_{i t} \quad$ Industry indicator variables (source: based on Worldscope data item 07021: SIC code). We specify the following industry indicators: (1) agriculture, forestry and fishing, (2) mining, (3) construction, (4) manufacturing, (5) transportation, communications, electric, gas, sanitary service, (6) wholesale trade, (7) retail trade, (8) finance, insurance and real estate, (9) services (10) public administration, (11) nonclassifiable.

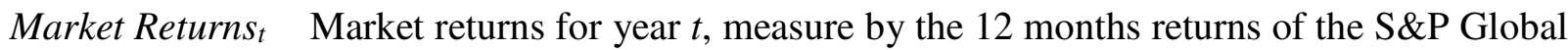
Broad Market Index for equities of year $t$ (source: S\&P website).

Payout Ratio $_{i t} \quad$ Common and preferred stock dividends paid by firm $i$ in year $t$, divided by net income (source: Capital IQ).

Shift $_{i t} \quad$ Indicator variable equal to one if firm $i$ terminates or freezes existing defined benefit pension plans, or transfers risk to insurance companies, in year $t$, and zero otherwise (source: hand-collection). 
Figure 1. Difference-in-differences research design

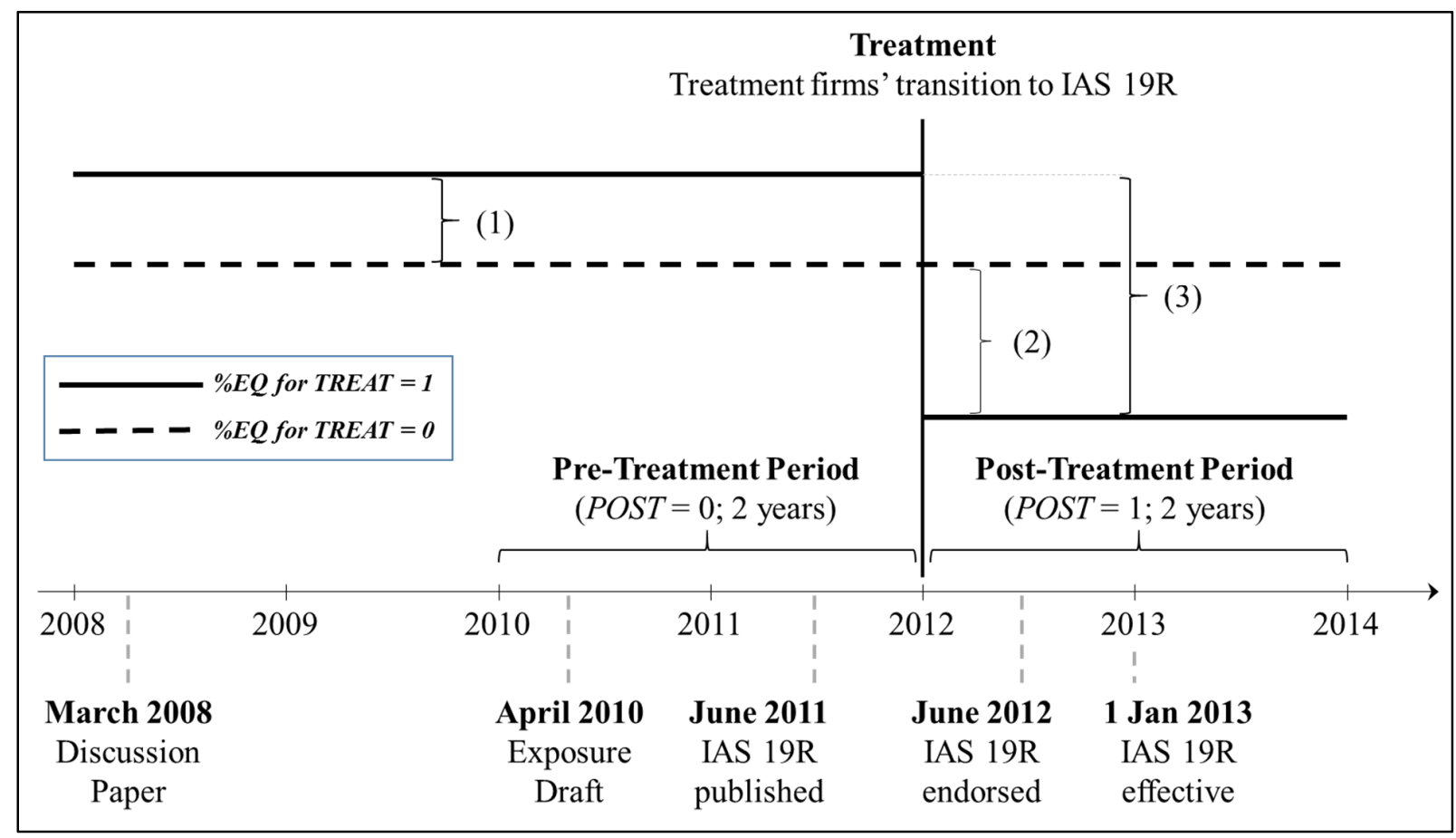

Figure 1 illustrates the difference-in-differences research design used in our main tests to identify the effect of IAS $19 \mathrm{R}$ on pension asset allocations. (Note that, whereas we observe two asset allocation characteristics, the percentage of equities, $\% E Q$, and the percentage of bonds, $\% B O N D S$, the figure only depicts one of them: $\% E Q$.) We observe $\% E Q$ and $\% B O N D S$ for two groups of firms: a treatment group affected by mandatory IAS 19R adoption (solid line) and a control group not subject to this accounting change (dotted line). The $Y$ axis of the graph depicts levels of $\% E Q$, and the $X$ axis represents a time line. Our research design measures differences in $\% E Q$ and $\%$ BONDS before (effect 1) and after (effect 2) the "treatment": the transition to IAS 19R. This difference-indifferences (effect 3 ) represents the causal treatment effect of IAS $19 \mathrm{R}$ on $\% E Q$ under the appropriate assumptions (refer to section 3.1). We use 2012 as the treatment date, as the introduction and details of IAS 19R were known to firms in mid-2011 (when it was published), although it was effective only for fiscal years beginning on 1 January 2013 or after. 
Figure 2. Equity and bond investments of treatment and control firms over time

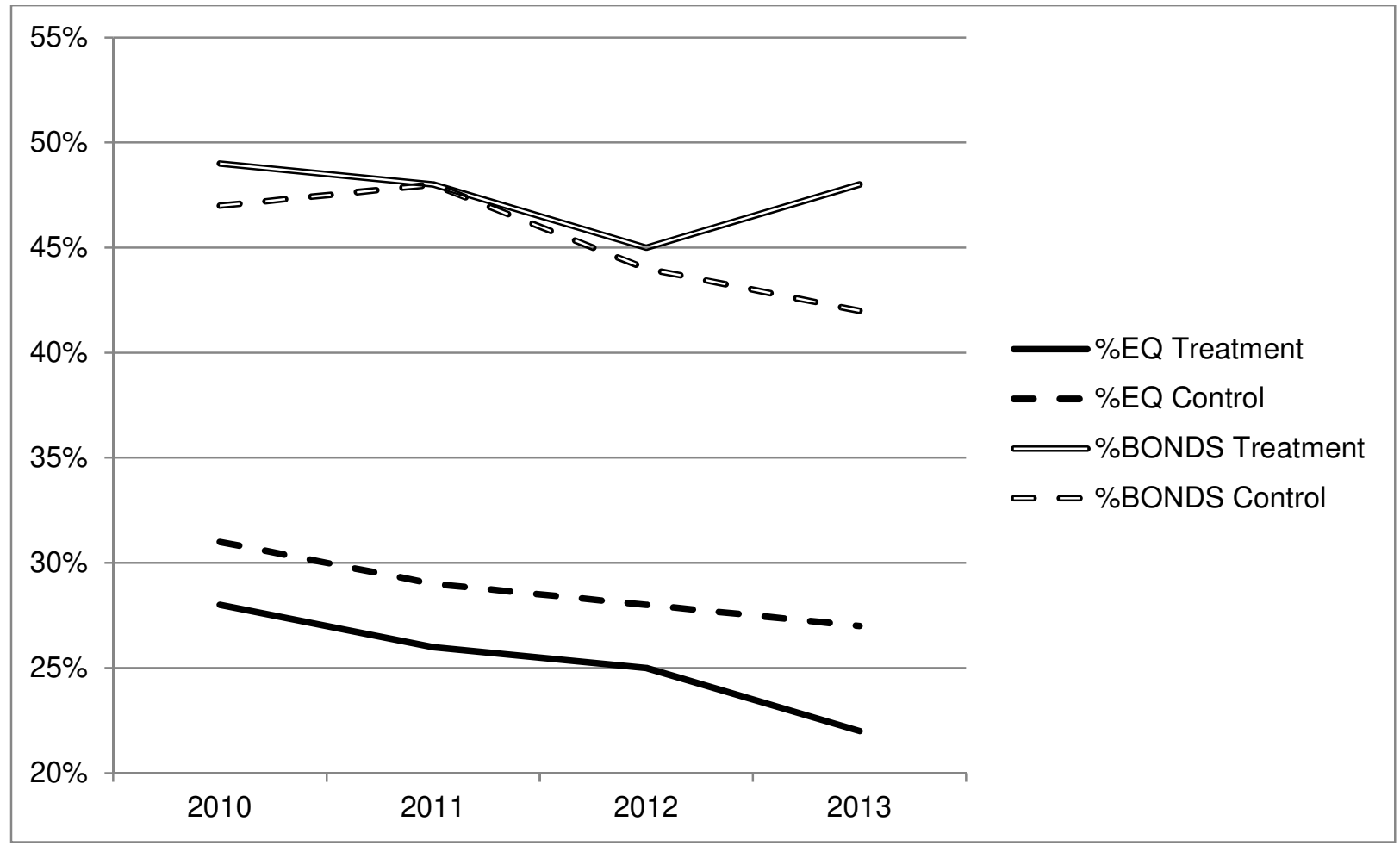

Figure 2 illustrates the two asset allocation characteristics, the percentage of equities $(\% E Q)$ and the percentage of bonds $(\% B O N D S)$, for the treatment group affected by mandatory IAS 19R adoption (solid lines) and a control group not subject to this accounting change (dotted lines), around the "treatment": mandatory adoption of IAS 19R. Both $\% E Q$ and $\% B O N D S$ exhibit relatively parallel trends in the years leading up to IAS 19R adoption, and drift apart subsequently. 
Table 1. Sample selection

Unique Firms

\begin{tabular}{lr}
\hline Number of firms listed within the Prime Standard & 319 \\
segment of Deutsche Börse Group, active as \\
of December 12, 2014. \\
Less firms \\
without defined benefit pension (DB) plans \\
without externally funded DB plans & -102 \\
that apply neither the corridor method & -45 \\
$\quad$ nor the OCI method prior to IAS 19R adoption & -17 \\
that fully fund pension plans with insurance contracts & -56 \\
that lack information on the pension asset allocation & -9 \\
\hline
\end{tabular}

$\frac{\begin{array}{c}\text { Corridor Method } \\ \text { (Treatment Firms) }\end{array}}{41} \quad \begin{gathered}\text { OCI Method } \\ \text { (Control Firms) }\end{gathered}$

Less firms

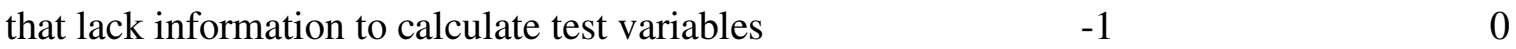

that are not listed in each year of the sample period

Firm-year observations per period

\begin{tabular}{r}
-3 \\
\hline 37 \\
$\mathrm{x} 4$ \\
148 \\
-40
\end{tabular}

$\begin{array}{r}-4 \\ \hline 45 \\ \mathrm{x} 4 \\ 180 \\ -72 \\ \hline\end{array}$

Less observations dropped during matching process

Firm-year observations used in main analyses (Table 3)

108

108

Table 1 presents the sample selection process. The initial sample consists of all firms listed within the Prime Standard segment of Deutsche Börse Group as of December 12, 2014. We exclude firms: (1) without defined benefit pension plans; (2) without externally funded defined benefit pension plans; (3) that recognize actuarial gains and losses in profit or loss; and (4) that fully fund pension plans with insurance contracts only. The remaining 90 firms are classified into the treatment and control groups according to their method of recognizing actuarial gains and losses. We exclude firms that lack sufficient data or observations, resulting in 37 unique treatment firms and 45 unique control firms. We analyze treatment and control firms over four periods, resulting in 328 firm-year observations; the final sample used in the main empirical analysis in Table 3 after matching treatment and control firms using propensity score matching includes 108 firm-year observations for treatment and 108 firm-year observations for control firms. 
Table 2. Summary statistics for the matched sample

Panel A: Descriptive statistics

Pre-Treatment Period (aggregated over 2010 and 2011)

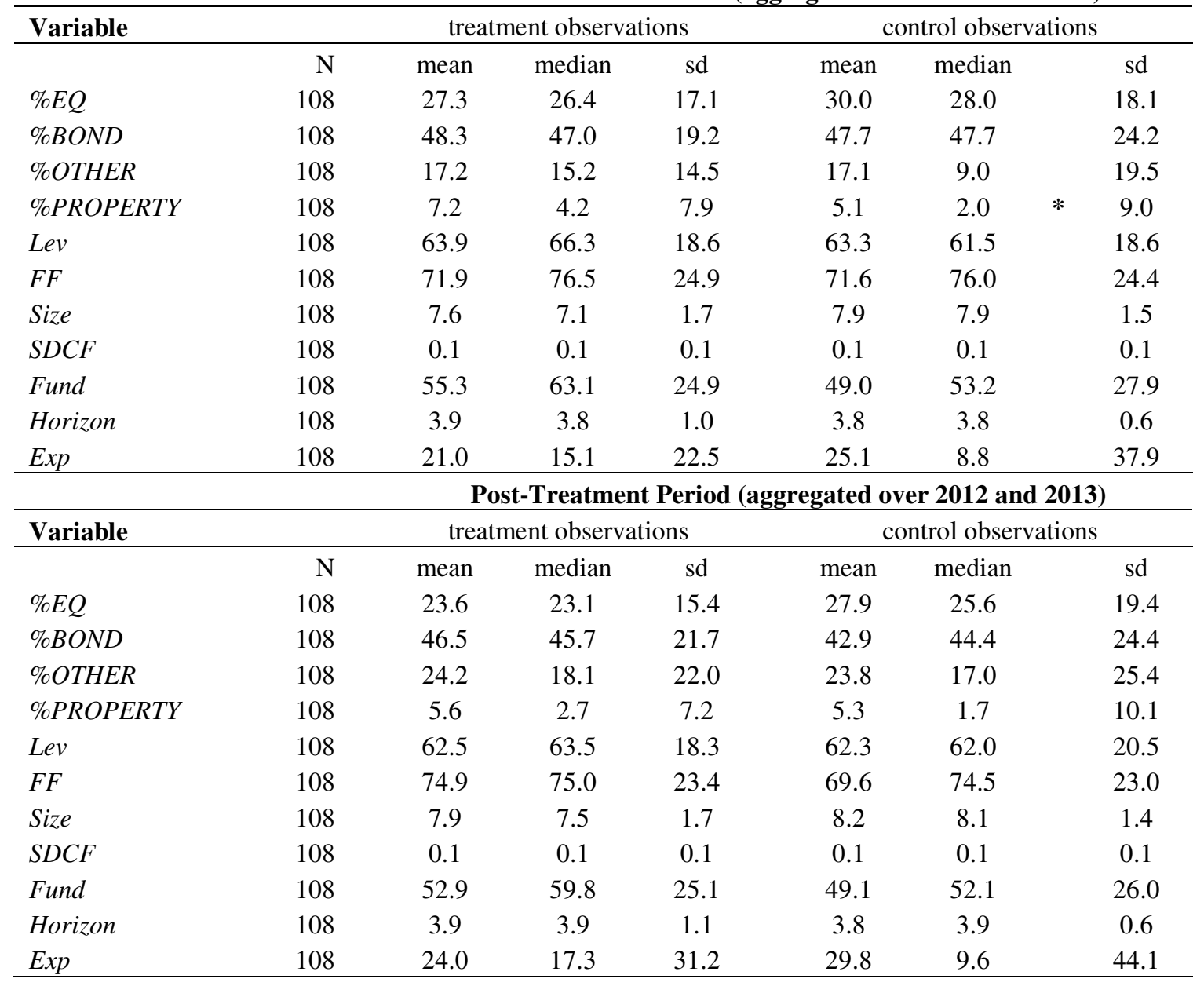


Panel B: Pearson and Spearman correlations

\begin{tabular}{|c|c|c|c|c|c|c|c|c|c|c|c|}
\hline Variable & $\% E Q$ & $\% B O N D$ & \%OTHER & \%PROPERTY & Lev & $F F$ & Size & $S D C F$ & Fund & Horizon & $\operatorname{Exp}$ \\
\hline$\% E Q$ & & $-0.44 * * *$ & $-0.30 * * *$ & $-0.18 * * *$ & 0.06 & $0.21 * * *$ & -0.04 & -0.01 & $-0.45 * * *$ & $0.27 * * *$ & 0.06 \\
\hline$\% B O N D$ & $-0.45 * * *$ & & $-0.65 * * *$ & $-0.11 *$ & $0.21 * * *$ & $-0.20 * * *$ & $0.19 * * *$ & 0.10 & $0.27 * * *$ & $-0.12 *$ & 0.03 \\
\hline \%OTHER & $-0.24 * * *$ & $-0.57 * *$ & & $-0.13 * *$ & $-0.29 * * *$ & 0.09 & $-0.12 *$ & $-0.12 *$ & 0.07 & -0.07 & $-0.15 * *$ \\
\hline \%PROPERTY & $-0.21 * * *$ & 0.07 & $-0.14 * *$ & & 0.04 & $-0.14 * *$ & $-0.12 *$ & 0.04 & 0.07 & -0.09 & 0.17 *** \\
\hline Lev & 0.06 & $0.18 * * *$ & $-0.23 * * * *$ & 0.10 & & $0.20 * * *$ & $0.39 * * *$ & $0.45 * * *$ & 0.03 & $0.13 *$ & 0.41 *** \\
\hline$F F$ & $0.15 * *$ & $-0.18 * * *$ & 0.08 & $-0.15 * *$ & $0.19 * * *$ & & 0.03 & 0.08 & 0.05 & $0.25 * * *$ & 0.16 ** \\
\hline Fund & $-0.40 * * *$ & $0.25 * * *$ & 0.15 ** & 0.09 & 0.02 & $0.13^{* *}$ & -0.05 & $0.15 * *$ & & $-0.26 * * *$ & $0.26 * * *$ \\
\hline Horizon & $0.21 * * *$ & $-0.14 * *$ & -0.06 & -0.04 & $0.22 * * *$ & $0.27 * * *$ & 0.00 & $0.34 * * *$ & $-0.19 * * *$ & & $0.11 *$ \\
\hline Exp & 0.06 & $0.11 *$ & -0.10 & $0.22 * * *$ & $0.53 * * *$ & $0.16 * *$ & 0.27 *** & $0.38 * * *$ & 0.36 *** & $0.25 * * *$ & \\
\hline
\end{tabular}

Table 2 provides descriptive statistics for the variables used in the main analyses of Table 3. Panel A provides descriptive statistics for the main variables of interest, split between the treatment group and the matched control group as well as the pre- and post-treatment periods.

Panel B provides correlation coefficients between the variables used in the empirical analysis. The upper (lower) diagonal shows Pearson (Spearman) correlation coefficients. $\% E Q$ is the percentage of equity investments, $\% B O N D S$ is the percentage of bond investments, \%OTHER is the percentage of other investments and \%PROP$E R T Y$ is the percentage of property investments. Lev is the leverage ratio defined as total liabilities divided by total assets, $F F$ is percentage of free float and is equal to the number of shares in free float divided by the total number of shares multiplied by 100, Size is the natural logarithm of the market value of equity, SDCF is the standard deviation of operating cash flows equal to the natural logarithm of the standard deviation of operating cash flows over the past 4 years divided by the book value of equity. Fund is the pension funding ratio defined as external pension assets divided defined benefit obligations and multiplied by 100. Horizon is the investment horizon of pension assets and is defined as the natural logarithm of the ratio of defined benefit obligations divided by the current service cost. Exp captures the exposure of a firm's book value of equity to the size of a pension plan and is defined as pension plan assets divided by the book value of equity multiplied by 100 . All continuous variables have been winsorized at the $1 \%$ level. *, **, *** indicate statistical significance at the $0.10,0.05$, and 0.01 levels, respectively (using a two-tailed test). 
Table 3. Effect of IAS 19R on the pension asset allocation (main tests of $\mathrm{H}_{1}$ and $\mathrm{H}_{2}$ )

Panel A: Univariate analysis

\begin{tabular}{|c|c|c|c|c|c|c|}
\hline \multirow[b]{2}{*}{$\% E Q$} & \multicolumn{2}{|c|}{ Pre-Treatment } & \multicolumn{2}{|c|}{ Post-Treatment } & \multicolumn{2}{|c|}{ Difference (Post-Pre) } \\
\hline & $N$ & Mean & $N$ & Mean & Change & $p$-value \\
\hline Treatment observations & 54 & 27.33 & 54 & 23.60 & -3.73 & 0.235 \\
\hline Control observations & 54 & 30.04 & 54 & 27.85 & -2.19 & 0.546 \\
\hline Difference & & & & & -1.54 & $0.10 *$ \\
\hline
\end{tabular}

\begin{tabular}{|c|c|c|c|c|c|c|}
\hline \multirow[b]{2}{*}{ \%BONDS } & \multicolumn{2}{|c|}{ Pre-Treatment } & \multicolumn{2}{|c|}{ Post-Treatment } & \multicolumn{2}{|c|}{ Difference (Post-Pre) } \\
\hline & $N$ & Mean & $N$ & Mean & Change & $p$-value \\
\hline Treatment observations & 54 & 48.27 & 54 & 46.53 & -1.74 & 0.658 \\
\hline Control observations & 54 & 47.68 & 54 & 42.91 & -4.77 & 0.310 \\
\hline Difference & & & & & 3.03 & $0.020 * *$ \\
\hline
\end{tabular}


Table 3. Effect of IAS $19 \mathrm{R}$ on the pension asset allocation (main tests of $\mathrm{H}_{1}$ and $\mathrm{H}_{2}$ ) (cont'd)

Panel B: Multivariate analysis - base model and tests of $\mathrm{H}_{1}$

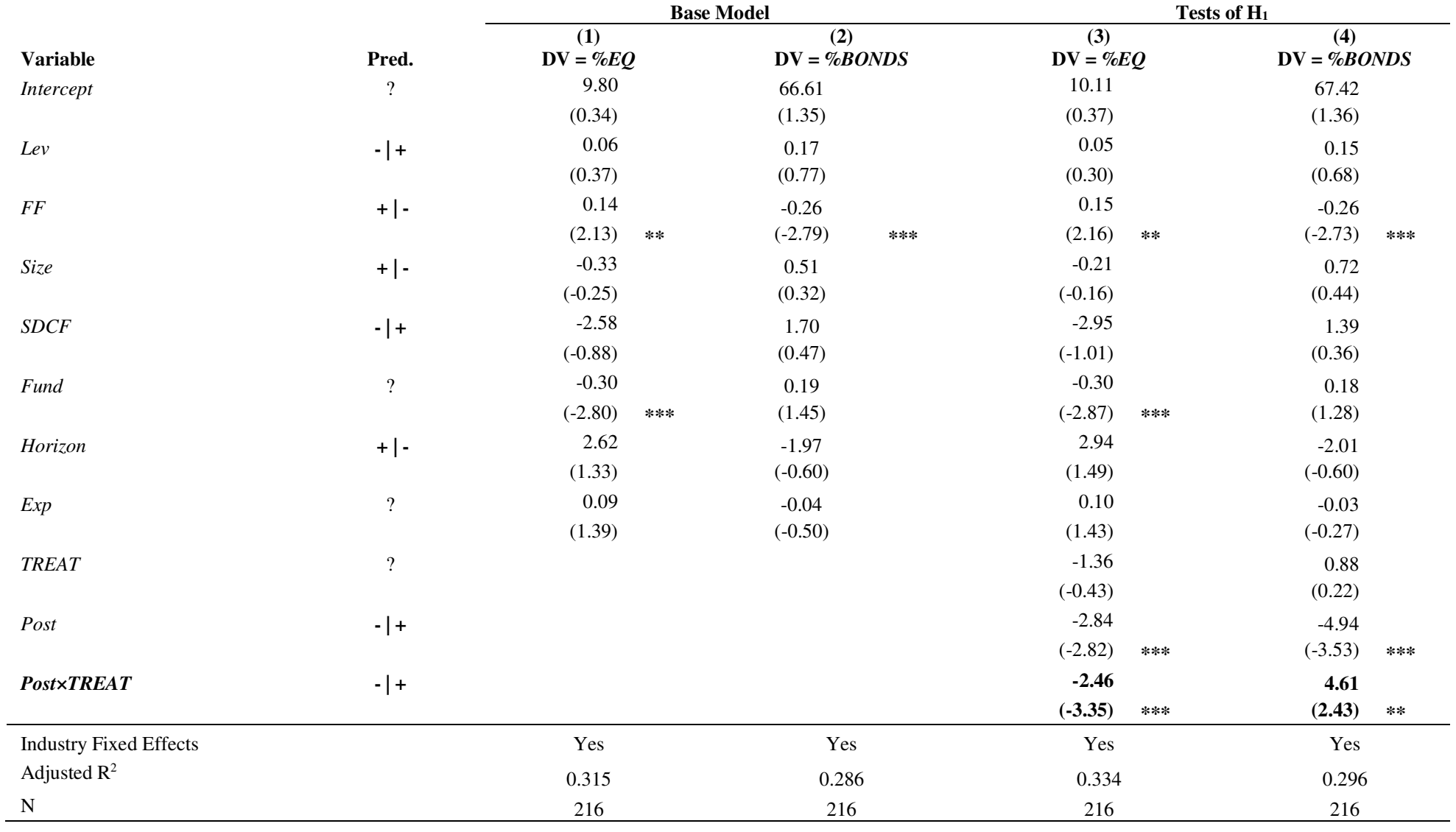


Table 3. Effect of IAS $19 \mathrm{R}$ on the pension asset allocation (main tests of $\mathrm{H}_{1}$ and $\mathrm{H}_{2}$ ) (cont'd)

Panel C: Multivariate analysis - tests of $\mathrm{H}_{2}$

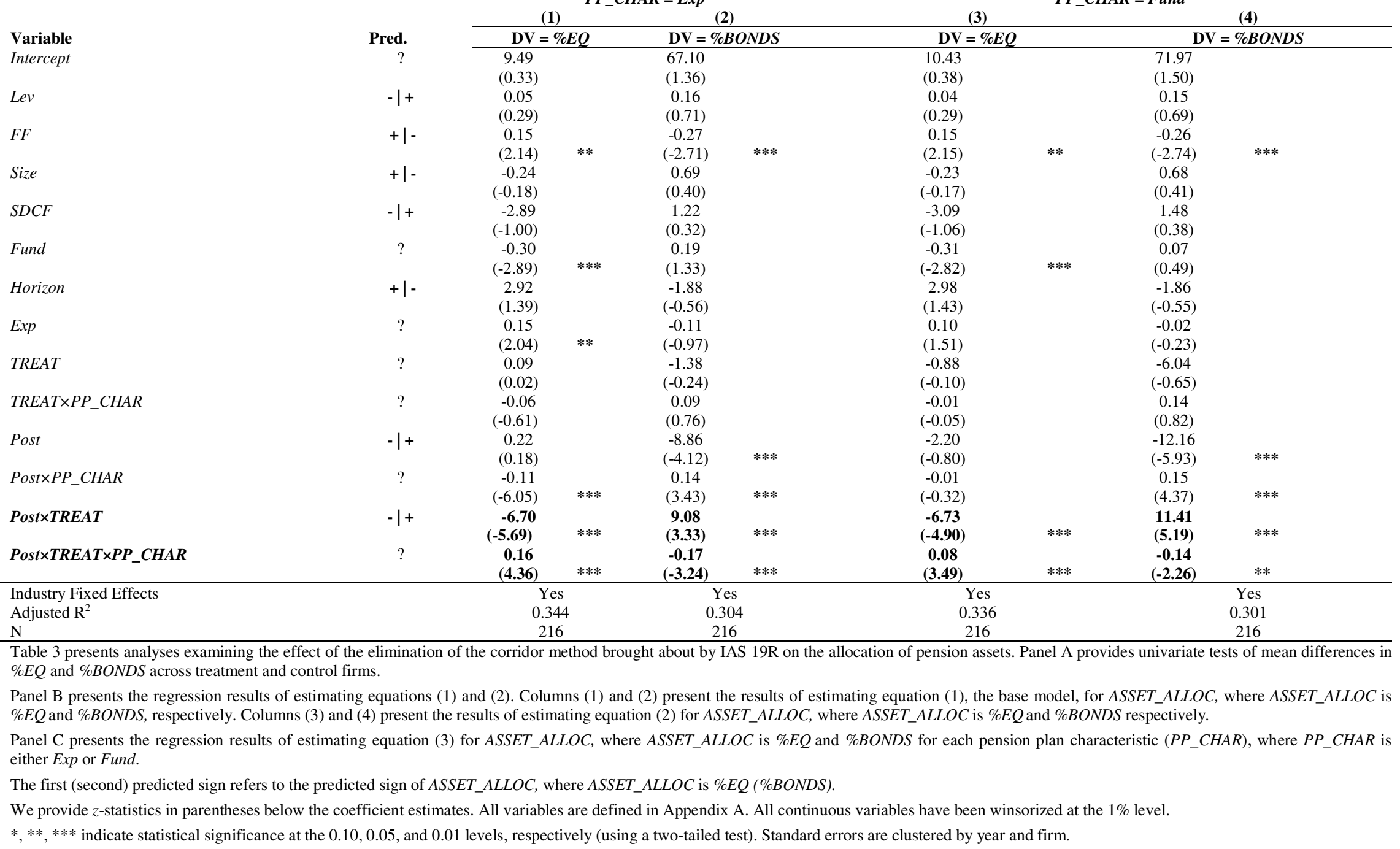


Table 4. Alternative analyses: Isolating the 'ERR Effect' of IAS 19R

\begin{tabular}{|c|c|c|c|c|c|c|c|c|}
\hline \multirow{3}{*}{ Variable } & \multicolumn{4}{|c|}{$P P \_C H A R=E x p$} & \multicolumn{4}{|c|}{$P P_{-} C H A R=$ Fund } \\
\hline & \multirow{2}{*}{\multicolumn{2}{|c|}{$\begin{array}{c}(1) \\
\mathrm{DV}=\% E Q\end{array}$}} & \multicolumn{2}{|l|}{ (2) } & \multicolumn{2}{|c|}{ (3) } & \multicolumn{2}{|c|}{ (4) } \\
\hline & & & $\mathrm{DV}=\% B C$ & & $\mathrm{DV}=$ & & $\mathrm{DV}=$ & \\
\hline Intercept & $\begin{array}{l}44.54 \\
(2.28)\end{array}$ & $* *$ & $\begin{array}{l}24.49 \\
(0.93)\end{array}$ & & $\begin{array}{l}33.76 \\
(1.81)\end{array}$ & $*$ & $\begin{array}{l}40.08 \\
(1.60)\end{array}$ & \\
\hline Lev & $\begin{array}{c}0.13 \\
(0.94)\end{array}$ & & $\begin{array}{c}-0.03 \\
(-0.15)\end{array}$ & & $\begin{array}{c}0.09 \\
(0.71)\end{array}$ & & $\begin{array}{c}-0.00 \\
(-0.01)\end{array}$ & \\
\hline$F F$ & $\begin{array}{c}0.16 \\
(2.20)\end{array}$ & $* *$ & $\begin{array}{l}-0.06 \\
(-0.57)\end{array}$ & & $\begin{array}{c}0.17 \\
(2.26)\end{array}$ & $* *$ & $\begin{array}{l}-0.08 \\
(-0.79)\end{array}$ & \\
\hline Size & $\begin{array}{c}-4.79 \\
(-5.35)\end{array}$ & & $\begin{array}{c}3.52 \\
(3.50)\end{array}$ & $* * *$ & $\begin{array}{c}-4.54 \\
(-5.68)\end{array}$ & $* * * *$ & $\begin{array}{c}3.39 \\
(3.64)\end{array}$ & $* * *$ \\
\hline$S D C F$ & $\begin{array}{c}-2.66 \\
(-0.94)\end{array}$ & & $\begin{array}{c}0.80 \\
(0.27)\end{array}$ & & $\begin{array}{l}-2.05 \\
(-0.91)\end{array}$ & & $\begin{array}{c}0.35 \\
(0.13)\end{array}$ & \\
\hline Fund & $\begin{array}{c}-0.05 \\
(-0.55)\end{array}$ & & $\begin{array}{l}-0.07 \\
(-0.60)\end{array}$ & & $\begin{array}{c}0.20 \\
(1.51)\end{array}$ & & $\begin{array}{l}-0.33 \\
(-2.16)\end{array}$ & $* *$ \\
\hline Horizon & $\begin{array}{c}3.74 \\
(1.02)\end{array}$ & & $\begin{array}{l}1.81 \\
(0.40)\end{array}$ & & $\begin{array}{c}3.81 \\
(1.07)\end{array}$ & & $\begin{array}{c}1.67 \\
(0.42)\end{array}$ & \\
\hline $\operatorname{Exp}$ & $\begin{array}{c}0.17 \\
(2.38)\end{array}$ & $* *$ & $\begin{array}{l}-0.01 \\
(-0.14)\end{array}$ & & $\begin{array}{c}0.05 \\
(0.99)\end{array}$ & & $\begin{array}{c}0.03 \\
(0.64)\end{array}$ & \\
\hline TREAT & $\begin{array}{l}-14.46 \\
(-3.37)\end{array}$ & $* * *$ & $\begin{array}{l}10.34 \\
(1.82)\end{array}$ & * & $\begin{array}{c}9.92 \\
(1.16)\end{array}$ & & $\begin{array}{l}-20.62 \\
(-2.01)\end{array}$ & *** \\
\hline TREAT $\times P P \_C H A R$ & $\begin{array}{c}-0.15 \\
(-1.87)\end{array}$ & $*$ & $\begin{array}{c}0.01 \\
(0.09)\end{array}$ & & $\begin{array}{c}-0.46 \\
(-3.61)\end{array}$ & $* * *$ & $\begin{array}{c}0.50 \\
(3.29)\end{array}$ & **** \\
\hline Post & $\begin{array}{c}0.79 \\
(1.12)\end{array}$ & & $\begin{array}{l}1.16 \\
(1.58)\end{array}$ & & $\begin{array}{l}-7.42 \\
(-4.32)\end{array}$ & $* * *$ & $\begin{array}{c}7.83 \\
(5.60)\end{array}$ & **** \\
\hline Post $\times P P \_C H A R$ & $\begin{array}{c}-0.05 \\
(-1.50)\end{array}$ & & $\begin{array}{l}-0.01 \\
(-0.52)\end{array}$ & & $\begin{array}{c}0.10 \\
(4.64)\end{array}$ & $* * *$ & $\begin{array}{l}-0.10 \\
(-7.61)\end{array}$ & **** \\
\hline Post $\times$ TREAT & $\begin{array}{c}1.98 \\
(1.54)\end{array}$ & & $\begin{array}{l}-11.01 \\
(-7.01)\end{array}$ & $* * *$ & $\begin{array}{c}7.00 \\
(2.75)\end{array}$ & $* * *$ & $\begin{array}{l}-12.08 \\
(-5.59)\end{array}$ & **** \\
\hline Post $\times$ TREAT $\times$ PP_CHAR & $\begin{array}{c}-0.03 \\
(-1.36) \\
\end{array}$ & & $\begin{array}{c}\mathbf{0 . 1 2} \\
(3.32)\end{array}$ & $* * *$ & $\begin{array}{c}-0.10 \\
(-2.90)\end{array}$ & $* * *$ & $\begin{array}{c}0.07 \\
(1.39)\end{array}$ & \\
\hline $\begin{array}{l}\text { Industry Fixed Effects } \\
\text { Adjusted } \mathrm{R}^{2} \\
\mathrm{~N}\end{array}$ & $\begin{array}{r}\mathrm{Ye} \\
0.4 \\
32 \\
\end{array}$ & & & & $\begin{array}{r}\mathrm{Y} \\
0.5 \\
32 \\
\end{array}$ & & & \\
\hline
\end{tabular}

Table 4 presents analyses designed to examine the 'ERR effect' on the allocation of pension assets. It reports regression results of estimating equation (3) for $A S S E T \_A L L O C$, where ASSET_ALLOC is \%EQ and \%BONDS for each pension plan characteristic (PP_CHAR), where PP_CHAR is either Exp or Fund.

We provide $z$-statistics in parentheses below the coefficient estimates. All variables are defined in Appendix A. All continuous variables have been winsorized at the $1 \%$ level.

$*, * *, * * *$ indicate statistical significance at the $0.10,0.05$, and 0.01 levels, respectively (using a two-tailed test). Standard errors are clustered by year and firm. 